\title{
ROLA IDEI NAŚLADOWANIA CHRYSTUSA W TEOLOGII MORALNEJ F. TILLMANNA
}

Rozpoczęta przed laty praca nad odnową, czy nawet gruntowną przebudową, teologii moralnej trwa nadal. O tym, że dzieło to nie zostało jeszcze ukończone, że nie znaleziono jakiegoś idealnego modelu teologii moralnej ${ }^{1}$, który by zyskał powszechne uznanie i. przyjęcie, świadczą nadal podejmowane próby nowych ujęć tej nauki; świadczy ustawicznie wzrastająca liczba publikacji i artykułów poświęconych tematowi odnowy tej dyscypliny teologicznej. Temu przekonaniu o nadal istniejącej konieczności odnowy dał również wyraz Sobór Watykański II, wzywając do skierowania szczególnej troski ku udoskonaleniu teologii moralnej ${ }^{2}$.

Teolog moralista, podejmując dzisiaj dzieło odnowy swej dyscypliny, nie może oczywiście pomijać dorobku swych poprzedników. Pewne bowiem tematy zostały już wypracowane i uchodzą za obowiązujące ${ }^{3}$. Synteza trwałego dorobku w dziedzinie odnowy teologii moralnej wymaga, rzecz jasna, opracowań monograficznych. Celowi temu chce właśnie służyć niniejsze opracowanie ukazujące wkład F. Tillmanna w dzieło odnowy teologii moralnej ${ }^{4}$. Ten bowiem boński biblista i moralista zarazem uchodzi za autora, którego idee skierowały rozwój teologii moralnej — przynajmniej niemieckiego obszaru językowego — na nowe tory ${ }^{5}$.

1 Fuchs J., Moral und Moraltheologie nach dem Konzil, Herder Freiburg im Br. 1967, 58.

¿ Sobór Watykański II, Konstytucje Dekrety Deklaracje. Pallottinum Poznań 1968, 463 (DFK 16).

${ }^{3} \mathrm{Za}$ taki temat uznaje ks. J. Pryszmont np. orientację chrystocentryczną. Por. tego autora, Wokót zagadnienia chrystocentryzmu $w$ teologii moralnej „Coll. Theol." 40 (1970), z. $1,15$.

${ }_{4}$ Tillmann Fritz ur. 1 XI 1874 r. w Honnef, zm. 24 III 1953 r. w Rhöndorf. Habilitowany $1908 \mathrm{r}$. w Bonn z egzegezy nowotestamentalnej. Wydał m. in. Pismo św. Nowego Testamentu (przekład i komentarz), z którego sam opracował t. 'III Ewangelię św. Jana. W latach 1913-1939 był profesorem teologii moralnej w Bonn; przez dwa lata (1919-1921) pelnił urząd rektora uniwersytetu bońskiego. Por. Hadrossek P., Tillmann Fritz. „Lexikon für Theologie und Kirche”, Herder Freiburg im Br. 1965, Bd X, 196.

5 Hörmann K., Geschichte der Moraltheologie. Lexikon der christlichen Moral, Tyrolia Verlag Innsbruck Wien München 1969, 489. Mayer J., Tillmann Fritz, Die Idee der Nachfolge Christi, Düsseldorf 1934, rec.: „Theologie und Glaube”, 26 (1934) 504.

26 - Analecta Cracoviensia 
Wkład F. Tillmanna w dzieło odnowy teologii moralnej rozpatruje się tu $\mathrm{w}$ tym szczególnym aspekcie, jaki stanowi zagadnienie tzw. zasady moralnej. Jak wiadomo, wśród moralistów podejmujących dzieło odnowy utrzymuje się przekonanie, iż zasadnicze znaczenie dla tej odnowy ma wybór właściwej zasady moralnej ${ }^{6}$. Zagadnienie to do dnia dzisiejszego jest przedmiotem ożywionej dyskusji. „Dotąd nie znaleziono jeszcze stwierdza G. Ermecke - takiej wszechstronnie zadowalającej zasady moralnej, chociaż poszukiwanie jej jest możliwe, konieczne i o wielkim znaczeniu praktycznym" ". Przedmiotem sporu jest nie tylko możliwość znalezienia takiej zasady moralnej, jej jasnego sformułowania i pełnej realizacji w systemie katolickiej nauki moralnej, lecz także samo pojęcie zasady, jej istotne przymioty i zadania. W zależności od punktu obranego przy poszukiwaniu zasady moralnej R. Hoffmann wyodrębnia dwie grupy zasad moralnych. Grupę pierwszą, nazwaną przez niego ujęciem systematycznym, stanowią zasady celu ostatecznego i miłości, a więc te zasady, przy których formułowaniu wychodzi się -od ostatecznej treściowej podstawy ludzkiej moralności, by dojść do całościowego rozumienia moralności chrześcijańskiej. W grupie drugiej, czyli w grupie podstawowych zasad w pierwszym rzędzie biblijnych, znajdują się zasady moralne wydobyte ze źródeł Objawienia, a więc takie zasady, jak idea królestwa Bożego, sakramentalnego upodobnienia do Chrystusa czy wreszcie idea naśladowania Chrystusa ${ }^{8}$.

Określiwszy w ten sposób miejsce niniejszego opracowania w całości problematyki odnowy teologii moralnej, można przystąpić do poszukiwania odpowiedzi na zasadnicze pytanie, które jest tu pytaniem o rolę idei naśladowania Chrystusa w teologii moralnej F. Tillmanna. Część pierwsza poświęcona jest odtworzeniu Tillmannowej koncepcji teologii moralnej, natomiast część druga podejmuje temat roli idei naśladowania Chrystusa w tym konkretnym ukształtowaniu teologii moralnej.

\section{TILLMANNOWA KONCEPCJA TEOLOGII MORALNEJ W OGOLNOSCI}

1. Teologia moralna nauką opartą na wierze

Nauka moralna Kościoła jest gałęzią teologii katolickiej. Twierdzenie to podzielane także przez F. Tillmanna ma zasadnicze znaczenie dla ustalenia właściwej natury katolickiej doktryny moralnej. Uprawnia ono bo-

${ }^{6}$ Hofmann R., Moraltheologische Erkenntnis - und Methodenlehre, M. Hueber München 1963, 217. Mausbach J. -Ermecke G., Katholische Moraltheologie, Aschendorffsche Verlagsbuchhandlung Münster W. 1959, Bd I, 25.

7 Ermecke G., Moralprinzipien. ,Lexikon für Theologie und Kirche”, Herder Freiburg im Br. 1962, Bd VII, 602-604.

8 Hofmann R., dz. cyt., 222 nn. 
wiem do wniosku, iż doktryna ta musi wykazywać istotne cechy nauki teologicznej.

Za jedną z cech nauki teologicznej, być może najbardziej podstawową, autor nasz uznaje to, że teologia stanowi szczególny, odrębny gatunek nauki: jest mianowicie nauką opartą na wierze (,Glaubenswissenschaft”) ${ }^{9}$. Przedmiotem teologii jest prawda wiary. Jako nauka o wierze, ma ona swój punkt wyjścia nie w czystym rozumie, lecz w Objawieniu Bożym. Jej zadanie polega na ujęciu w pojęcia i na systematycznym uporządkowaniu treści Objawienia ${ }^{\mathbf{1 0}}$.

Stanowiąc gałąź teologii katolickiej, nauka moralna Kościoła również jest nauką opartą na wierze, co wyraźnie na wielu miejscach stwierdza nasz moralista ${ }^{11}$. Jak wiadomo, problematyka moralna nie stanowi wyłącznej domeny teologii, wszak zajmuje się nią także filozofia. Jednakże pomiędzy teologiczną a czysto filozoficzną nauką moralną zachodzi istotna różnica. Określając katolicką doktrynę moralną mianem „,Glaubenswissenschaft", zaznaczamy naprzód słownie tę właśnie różnicę. Wszelka bowiem czysto filozoficzna nauka moralna, a w szczególności tzw. etyka niezależna (,die sog. immanente Ethik”), jest tylko i wyłącznie nauką rozumową - „Vernunftwissenschaft" ${ }^{12}$. Określenia te oczywiście zawierają w sobie pewną treść, która pozwala nam poznać, na czym polega owa istotna różnica pomiędzy teologiczną a czysto filozoficzną nauką moralną. Uwidacznia się ona przede wszystkim w odmiennych zasadniczych źródłach poznania. Jako nauka oparta na wierze, doktryna moralna Kościoła ma swoje najdoskonalsze i najwłaściwsze źródło (,die vorzüglichste, ureigenste Quelle") w Objawieniu Bożym. Przy czym przez Objawienie Boże autor rozumie jego całokształt, czyli to wszystko, co zawiera się w Piśmie św. i Tradycji, i co Urząd Nauczycielski Kościoła nienaruszenie strzeże i nieomylnie głosi ${ }^{13}$. Z tym Objawieniem katolicka nauka moralna jest zasadniczo i wszechstronnie związana, i to zarówno pod względem metodycznym, jak i treściowym ${ }^{14}$. W rozumieniu Tillmanna miano ,Glaubenswissenschaft" wyraża właśnie ten podwójny związek teologii z Objawieniem. I dlatego zadaniem katolickiej doktryny moralnej jest ,przede wszystkim ująć religijno-moralną zawartość Pisma św. i uczynić z niej

${ }^{9}$ Tillmann F., Handbuch der Katholischen Sittenlehre, Bd III: Die Idee der Nachfolge Christi, Patmos Verlag Düsseldorf 1953, 9. Odtąd dzieło to będzie cytowane w skrócie: Nachf. Chr.

10 Nachf. Chr., 10, 24.

11 Nachf. Chr., 9, 21 n., Przedm. Por. także Tillmann F., Um eine Katholische Sittenlehre. Menschenkunde im Dienste der Seelsorge und Erziehung, Trier 1948, 10 n., oraz Tillmann F., Katholische Sittenlehre. Patmos Verlag Düsseldorf 1954, Przedm.

12 Nachf. Chr., 21; Tillmann F., Um eine Katholische Sittenlehre. Menschenkunde im Dienste der Seelsorge und Erziehung, Trier 1948, 10 Odtąd artykuł ten będzie cytowany w skrócie: Um $k$. Sitt.

13 Nachf. Chr., 9, 14, 22, Przedm.

14 Nachf. Chr., 9. 
kształtującą zasadę, jak i treść swego przedstawienia" ${ }^{15}$. W świetle zacytowanego tu zdania naprzód religijno-moralna zawartość Pisma św. ma kształtować wykład teologii moralnej. Wydaje się, że w tym właśnie kształtowaniu widzi autor zależność moralnej od Objawienia pod względem metodycznym. O wiele jaśniej przedstawia się natomiast sprawa zaleznośçi co do treści. Religijno-moralna zawartość Pisma św. ma po prostu stanowić treść wykładu naszej dyscypliny. Szczególnym wyrazem tego rodzaju zależności jest fakt pochodzenia ze wspomnianego źródła podstawowych pojęć katolickiej nauki moralnej. Uzdolnienie i zobowiązanie człowieka do odpowiedzialnego działania moralnego, pojęcie grzechu, woli Bożej jako najwyższej normy moralnej i jako źródła zobowiązania moralnego; prawda o nadprzyrodzonym celu i darach łaski, z pomocą których winno się go osiągnąć - wszystko to, zdaniem F. Tillmanna, zalicza się do powyższej kategorii pojęć. Moralna katolicka, podchodząc do problematyki etycznej w świetle wiary, nie rezygnuje bynajmniej z usług rozumu. Nie jest to już jednak rozum zdany na samego siebie, lecz rozum oświecony wiarą chroniącą go od błędu ${ }^{16}$.

Określając katolicką doktrynę moralną mianem nauki opartej na wierze, chcemy ją odróżnić od czysto filozoficznej nauki moralnej, w szczególności zaś od tzw. etyki niezależnej. Jeśli w ślad za autorem poświęcamy z kolei nieco uwagi tej ostatniej, czynimy to w tym celu, by jeszcze bardziej uwidoczniła się właściwa natura katolickiej teologii moralnej jako nauki opartej nie na samym rozumie, lecz na wierze. Można sądzić, iż w przekonaniu F. Tillmanna miano etyki niezależnej nadaje się tej czysto filozoficznej nauce morałnej w pierwszym rzędzie dlatego, że dąży ona do całkowitego uniezależnienia się od Boga. Powiada bowiem nasz moralista, że etyka ta ,na wszelkie sposoby pomija Boga i Jego postępowanie z człowiekiem w. porządku natury i łaski, stworzenia i objawienia" 17. Zasadnicze zadania etyki, jak wykazanie istnienia świata norm i wartości moralnych, wskazanie ostatecznej podstawy orzekania dobra i zła moralnego, określenie miary i granic powinności moralnej, usiłuje ona spełnić jedynie z pomocą samego tylko poznania rozumowego. Autor z naciskiem podkreśla, że pomiędzy tego rodzaju nauką moralną a doktryną etyczną Kościoła zachodzi istotna różnica.

W naszych dotychczasowych rozważaniach staraliśmy się odpowiedzieć na pytanie, jaka jest właściwa natura teologicznej nauki moralnej. Odpowiedź ta była dwustopniowa: naprzód pozytywna - katolicka doktryna moralna jest nauką opartą na wierze; a następnie negatywna - katolicka doktryna moralna nie jest nauką opartą na samym tylko rozumie,

15 Nachf. Chr. Przedm., 5.

16 Nachf. Chr., 22.

17 Nachf. Chr., 21. 
jak to ma miejsce zwłaszcza w wypadku tzw. etyki niezależnej. Ten fakt, że katolicka teologia moralna jest nauką opartą na wierze, pociąga za sobą szereg doniosłych następstw. Będzie o nich mowa później, mianowicie przy zagadnieniu źródeł i podstaw katolickiej nauki moralnej. Tu chcemy się zając jedynie tym szczególnym następstwem, jakim jest sprawa pierwszeństwa teologii moralnej wśród różnych odcieni czysto filozoficznych systemów etycznych. Dzięki temu jeszcze mocniej uwidoczni się właściwa natura doktryny moralnej Kościoła jako nauki opartej na wierze.

O tym prymacie stanowią przede wszystkim trzy cechy teologicznej nauki moralnej. Pierwszą z nich można by wyrazić słowami: jako nauka oparta na wierze, katolicka doktryna moralna zawiera o wiele bogatszą treść niż czysto filozoficzna etyka. W Objawieniu Bożym znajduje ona mianowicie szereg prawd o zasadniczym znaczeniu dla życia moralnego, które nie są dostępne poznaniu rozumowemu. Autor nasz zalicza tu naukę o nadprzyrodzonym celu, jaki Bóg wyznaczył działaniu moralnemu człowieka. Prawda ta rozstrzyga o zasadniczym nastawieniu chrześeijanina i uczy go patrzeć na siebie i to, co ma z nim związek, pod kątem wieczności. Należy tu również nauka o grzechu pierworodnym i o odkupieniu. Poznanie spowodowanej grzechem pierworodnym słabości rozumu i woli zabezpiecza katolicką naukę moralną przed fałszywym optymizmem etycznym. Z drugiej strony nauka o odkupieniu przez Jezusa Chrystusa i o sile Jego łaski chroni doktrynę moralną Kościoła przed pesymizmem, który wątpi w możliwość urzeczywistnienia doskonałości chrześcijańskiej. Także w wielu szczegółowych kwestiach moralnych posiada ona w Objawieniu ostatecznie rozstrzygające słowo, dzięki któremu wznosi się ponad wszelką wątpliwość i niepewność ${ }^{18}$.

Druga $\mathrm{z}$ owych cech dotyczy mocy wiążącej wymagań stawianych przez katolicką naukę moralną. Zdaniem autora etyka nie może zapewnić swym normom tego stopnia siły wiążącej, jaką posiadają normy doktryny moralnej Kościoła. Nie jest ona w stanie uzasadnić absolutnego charakteru wymagań moralnych. W szczególności etyka niezależna żadną miarą nie jest zdolna dać ostatecznego uzasadnienia wartości moralnych. Może ona co najwyżej ukazać ich odpowiedniość i użyteczność czy też nieodzowność dla pomyślnego rozwoju jednostki bądź społeczności. Wszystkie te trudności odpadają w przypadku teologicznej nauki moralnej. Tu bowiem ,za normą, jak i za konkretnym wymaganiem stoi objawiona wola osobowego Boga" i dlatego ,dla człowieka wierzącego i norma, i konkretne wymaganie są wolne od wszelkiej wątpliwości, zobowiązanie urzeczywistnia się bezpośrednio w rdzeniu osobowości, we własnym sumieniu" ${ }^{19}$. Nie może tutaj być mowy o błędzie co do wymagania, które 
się powinno spełnić; o podważaniu wewnętrznego, zgodnego z sumieniem zobowiązania, by zadośćuczynić owemu wymaganiu. Choć zasadniczo jest to prawdą - powiada autor - nie można jednak bez żadnych zastrzeżeń utrzymywać, że naturalne sumienie zawsze pokazuje to, co prawe, stając się jednocześnie źródłem koniecznego, wewnętrznego zobowiązania. Pozostawione samo sobie, nie korygowane wolą Bożą, naturalne sumienie dość często staje się ofiarą błędu i zafałszowania.

Trzecia wreszcie cecha odnosi się do skuteczności rozumianej jako realizacja norm. F. Tillmann twierdzi, że katolicka nauka moralna dysponuje skuteczniejszymi motywami i środkami pomocy niż etyka. Czynić dobro ze względu na dobro jest wzniosłą zasadą. Ale nawet wówczas, gdy dobro zostaje poznane w sposób pewny, brakuje mu „tego porywającego ciepła, tej siły wyzwalającej nawet i to, co najgłębsze w człowieku, która jest właściwa wielkiej i głębokiej miłości Boga" ${ }^{20}$. W swym uzasadnieniu postępowania moralnego nauka katolicka ukazuje szereg motywów poczynając od bojaźni Bożej a kończąc na miłości Boga. Motywy te nie tylko prowadzą człowieka ku coraz bardziej wartościowemu ustosunkowaniu się do wymagania moralnego, lecz także same w sobie posiadają taką wewnętrzną treść, że nie spotyka się ich poza światem religii i mającego w nım źródło etosu. Nadto z Ofiary i sakramentów chrześcijanin może czerpdc siły zdolne przemienić grzesznika w świętego.

Rozważając nad naturą katolickiej doktryny moralnej jako nauki opartej na wierze, nie można pominąć zagadnienia jej naukowości. Moralna katolicka jest prawdziwą nauką, aczkolwiek - jak nieustannie to za autorem podkreślamy - stanowi szczególnego rodzaju naukę. Zgodnie ze swoją istotą doktryna ta „nie może być niczym innym jak naukowym wypracowaniem i przedstawieniem chrześcijańskiego życia moralnego, jego zadań i obowiązków, jak są one zawarte w nadprzyrodzonym Objawieniu, dokładniej - w nauczaniu Pana" ${ }^{21}$. W świetle tej wypowiedzi nie tylko treść katolickiej nauki moralnej musi być naukowo wypracowana, czyli wydobyta ze źródeł przy pomocy odpowiedniej metody. Także przedstawienie tej treści, jej wykład, winny wykazywać znamię naukowości. A wiadomo, że „Pismo św. jest pisane językiem popularnym i rzeczy nawet najbardziej oderwane wyraża językiem obrazowym, pozbawionym ścisłości naukowej" ${ }^{22}$. Po wtóre, o czym będzie mowa przy charakterystyce zródeł, nie daje ono ani pełnego, ani systematycznego wykładu nauki moralnej. I dlatego teologia moralna, jako nauka, nie poprzestaje na ustaleniu sensu formuł, którymi posługuje się Pismo św., na wydobyciu ze źródeł i ujęciu w pojęcia treści objawionej. Chcąc być nau-

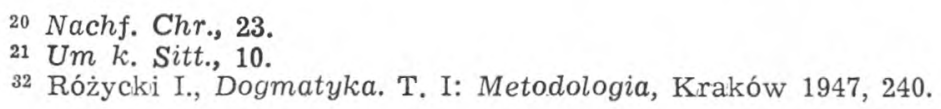


ką, musi ona uporządkować tę treść, dać jej systematyczny wykład. W tych właśnie dwóch funkcjach wyraża się naukowy charakter teologii moralnej. Wyraźnie stwierdza to sam autor, gdy pisze, że katolicka doktryna moralna jest nauką, ,ponieważ wydobywa ona ze źródeł wymagania moralne Jezusa i Jego apostołów, i porządkuje je według określonych punktów widzenia, jakie rozum ludzki podaje naukowemu opracowaniu" ${ }^{23}$.

\section{2. Źródła katolickiej nauki moralnej}

Spośród różnych czynników stanowiących o naturze jakiejś nauki na jedno z naczelnych miejsc wysuwają się z pewnością właściwe jej źródła poznania. Jeśli — jak widzieliśmy — źródłem poznania moralnego jest tylko rozum, mamy do czynienia z etyką czysto filozoficzną; jeśli zaś tym źródłem jest Objawienie Boże, mamy do czynienia z teologią moralną. Wprawdzie o źródłach katolickiej nauki moralnej była już częściowo mowa wyżej, niemniej temat ten domaga się dokładniejszego opracowania z uwagi na jego związek z zagadnieniem wystarczalności idei naśladowania Chrystusa do zbudowania teologii moralnej.

\section{A. Objawienie B oże}

Jako nauka oparta na wierze, katolicka doktryna moralna ma swoje najdoskonalsze, najwłaściwsze źródło w Objawieniu Bożym ${ }^{24}$. Jak już również wiadomo, przez Objawienie Boże autor rozumie jego całokształt, czyli ,jak jest ono zawarte w Piśmie i Tradycji, i przez Urząd Nauczycielski Kościoła jest nienaruszenie strzeżone i nieomylnie głoszone" ${ }^{25}$.

\section{a. Pismo św.}

„Najdoskonalszym źródłem, z którego katolicka nauka moralna czerpie swoje poznanie moralne i wymagania - pisze F. Tillmann - jest Pismo św. Starego i Nowego Testamentu" ${ }^{26}$. Gdy idzie naprzód o wzajemny stosunek tych dwóch stopni historycznego rozwoju Objawienia Bożego, to autor zwraca uwagę na fakt, że Stary Testament jest „cieniem przyszłych dóbr" nie tylko odnośnie do prawdy wiary, która pełny rozwój znalazła w Osobie i nauce wcielonego Syna Bożego, lecz jest owym „cieniem” także co do nauki moralnej. Zwłaszcza w Kazaniu na Górze Pan Jezus określił swoje stanowisko względem Prawa i Proroków, streszczające się w tym, że nie przyszedł ich znieść, ale wypełnić, udoskonalić.

23 Tillmann F., Katholische Sittenlehre, Patmos Verlag Düsseldorf 1954, 9. Odtąd dzieło to będzie cytowane w skrócie: K. Sitt.

${ }_{24}$ Nachf. Chr., 14, 22, Przedm.

25 Nachf. Chr., 9.

${ }^{26}$ Nachf. Chr., 14. 
Przejdźmy z kolei do charakterystyki Nowego Testamentu jako źródła teologii moralnej. Najpierw autor zauważa, że Nowy Testament nie jest zbiorem gotowych, wypracowanych już norm ${ }^{27}$. Nie mamy tu do czynienia z czymś w rodzaju kodeksu praw, w którym bez trudności można by odnaleźć wymagania moralne w formie ważnej dla wszystkich czasów. Przeciwnie, przed teologią moralną otwiera się tu szerokie pole pracy. Na tym m. in. polega jej zadanie, by odróżniła zewnętrzną formę przekazu Objawienia od wewnętrznej treści, czasowo-historyczne uwarunkowanie od ponadczasowej mocy wiążącej, i w ten sposób odnalazła właściwą wolę Jezusa Chrystusa i Jego naukę. Zadanie to jest często dość trudne, z uwagi na pewne braki i rozbieżności w źródłach wydaje się ono autorowi niekiedy $\mathrm{w}$ ogóle nie do rozwiązania. Ustalenie stosunku Pana Jezusa do bogactwa i ubóstwa może służyć jako przykład tego rodzaju trudności. Ogólniej rzecz biorąc ocena stanowiska Chrystusa względem tego świata i jego dóbr jest w przekonaniu autora równie skomplikowanym zagadnieniem. Nasuwa się mianowicie pytanie, czy postawa Jezusa w stosunku do nich jest immanentna, tzn. czy dojrzał On i docenil ich własną wewnętrzną wartość, czy też na sprawy te patrzył jedynie z religijnego punktu widzenia, czyli pod kątem ich znaczenia, jakie mają dla duszy i jej zbawiènia wiecznego. Czy w ogóle, zapytuje F. Tillmann, jest rzeczą możliwą wydobyć w tym względzie z Nowego Testamentu normy moralne dla całkiem innego świata i czasu, dla ludzi żyjących w zupełnie innych warunkach społeczno-ekonomicznych? Przyznaje on, że Ewangelia zawiera także moralne zasady i wymagania nie uwarunkowane czasowo-historycznymi powiązaniami, a więc takie normy moralne, które są ważne dla wszystkich czasów i wszystkich ludzi. Ale nawet w przypadku tak jasnego przykazania, jakim jest przykazanie miłości bliźniego jak siebie samego, nie sposób nie dostrzec, jak trudna staje się jego interpretacja i zastosowanie w dzisiejszym niezwykle skomplikowanym życiu gospodarczym.

Dalszą cechą nauki moralnej Nowego Testamentu jest to, że nie stanowi ona pełnego, wyczerpującego zestawu norm życia chrześcijańskiego ${ }^{28}$. Nauczanie Chrystusa jest wprawdzie nasycone religijno-moralnymi zasadami i wymaganiami, ale nie jest ono bynajmniej pełnym wykładem nauki moralnej. Byłby w błędzie, kto by sądził, że Pan Jezus dał możliwie najbardziej kompletne wyliczenie poszczególnych przepisów, z pomocą których można by normować postępowanie w różnych sytuacjach życiowych. Najczęściej dorywczo i z jakiegoś szczególnego powodu podawał wskazania moralne, upomnienia i ostrzeżenia. Można powiedzieć, że to wszystko wypływało z potrzeb chwili. Słuchaczom zaś swoim pozostawił

27 Nachf. Chr., 15 n.

28 Nachf. Chr., 27. 
wyprowadzenie z tych konkretnych rozstrzygnięć zasadniczych rysów, jakie musi wykazywać ich istota i postępowanie, jeśli chcą zaliczać się do Jego uczniów. Już apostołowie w chwili zetknięcia się chrześcijaństwa ze światem grecko-rzymskim stanęli wobec problemów życia religijno-moralnego - i to zarówno w wymiarze indywidualnym, jak i społecznym - dla których nie mieli żadnych gotowych rozstrzygnięć w nauczaniu Chrystusa ${ }^{29}$. Świadczą o tym zwłaszcza Listy św. Pawła do Rzymian i Koryntian oraz Dzieje Apostolskie. Tak np. Pierwszy List do Koryntian w znacznej mierze jest odpowiedzią Apostoła na pytania gminy korynckiej. W sprawach, co do których nie było ,nakazu Pańskiego", musieli decydować poszczególni Apostołowie lub ich ogół (Sobór Apostolski) na mocy swego apostolskiego urzędu i zamieszkującego w nich Ducha Sw. Gdy brak było gotowych rozstrzygnięć, byli oni zmuszeni odpowiedzieć na aktualne pytania „w duchu swego Mistrza” w oparciu o charyzmat apostolski.

Charakteryzując religijno-moralną treść Pisma św., trzeba na koniec i to podkreślić za autorem, że nie daje nam ono systematycznej nauki moralnej ${ }^{30}$. Wspomniano już wyżej, iż wskazania moralne Jezusa czy Apostołów były czymś okolicznościowym, przypadkowym. Stanowiły one odpowiedź na konkretne pytania, albo też dotykały problemów moralnych jakby przy sposobności (tak np. po odejściu bogatego młodzieńca Chrystus zabiera głos w sprawie bogactwa i ubóstwa). Pan Jezus nie stworzył więc żadnego gotowego systemu nauki moralnej, w którym by różnym przejawom życia moralnego wyznaczył właściwe im miejsce.

\section{b. Tradycja kościelna}

$\mathrm{Na}$ początku rozważań nad zagadnieniem źródeł teologii moralnej stwierdziliśmy, że autor nasz za najdoskonalsze źródło tejże nauki uznaje Objawienie Boże w jego całości, czyli jak się ono zawiera w Piśmie św. i Tradycji. Innymi słowy, wykład teologii moralnej nie ogranicza się do etycznej treści samego tylko Pisma św., gdyż „drugie źródło katolickiej nauki moralnej płynie w Tradycji kościelnej, która przyłącza się do Pisma św." jako jego uzupełnienie i kontynuacja ${ }^{31}$. Chodzi tu naprzód o urzędowe orzeczenia doktrynalne soborów powszechnych i papieży, które dotyczą bądź zasadniczych kwestii życia moralnego, bądź także poszczególnych przypadków. Obok tych nieomylnych orzeczeń Urzędu Nauczycielskiego Kościoła (magisterium extraordinarium) również zwyczajne nauczanie kościelne (magisterium ordinarium) stanowi obfite źródło teologii moralnej. Gdy jest ono nauczaniem powszechnym, ma charakter wiążący. Autorytatywne i wiążące jest także zgodne nauczanie Ojców

29 Nachf. Chr., 18, 28 n.

30 Nachf. Chr., 27.

31 Nachf. Chr., 17. 
Kościoła i teologów. Podobnie jak przy nauczaniu zwyczajnym Kościoła, tak i tu jednym z zadań teologii moralnej jest ustalenie, czy zachodzi owa powszechność, zgodność nauczania.

Tradycja kościelna, podkreśla àutor, ma charakter dynamiczny, rozwija się. Życie wraz ze zmianą stosunków kulturalnych i ekonomicznych przynosi z sobą wciąż nowe problemy, które Kościół musi rozwiązać w duchu otrzymanego od Chrystusa dziedzictwa. Nie chodzi tu oczywiście o jakieś pomnożenie tego co zasadnicze, wzrasta jedynie materiał, który wymaga chrześcijańskiego osądu moralnego.

\section{c. Osobowość Chrystusa}

Pismo św. i Tradycja oraz poznanie rozumowe należą do tych źródeł, które można by nazwać tradycyjnymi w tym sensie, że zasadniczo przyjmowali je wszyscy teologowie moraliści. Pewne „novum” natomiast stanowi uznanie za źródło poznania żywej osobowości Chrystusa, co jest związane z koncepcją teologii moralnej jako nauki o naśladowaniu Chrystusa. „Skoro pole chrześcijańskiej działalności moralnej — pisze F. Tillmann - leży pomiędzy dwoma biegunami (jakimi są) wzór i naśladowanie Chrystusa, wtedy jedno z najdoskonalszych zródeł poznania moralnego musi leżeć w żywej osobowości Pana" ${ }^{32}$.

$\mathrm{Na}$ zakończenie relacji o źródłach nasuwa się uwaga dotycząca faktycznej realizacji wysuniętych tu przez F. Tillmanna postulatów. Treść swej moralnej czerpie on zasadniczo z Pisma św. Nowego Testamentu, natomiast Tradycję kościelną uwzględnia w bardzo znikomej mierze.

\section{B. Poznanie rozumowe}

„Do podstawowych poglądów myślenia katolickiego - stwierdza autor - należy to, że uznaje ono naturalne poznanie rozumowe za źródło, z którego mogą być czerpane moralne prawdy i normy" ${ }^{33}$. W sumieniu dochodzi do głosu wszczepione człowiekowi przez Boga naturalne prawo moralne wraz ze swymi wymaganiami. Z reguły głos ten jest wyrazem obiektywnego stanu rzeczy, mianowicie stworzonego przez Boga porządku moralnego, którego urzeczywistnienie jest zadaniem człowieka. Historia i doświadczenie uczy jednak, że rozum może się mylić, że sąd sumienia może być błędny. Dlatego potrzebuje on sprawdzianu i znajduje go w Objawieniu Bożym. Ponieważ od Boga pochodzi zarówno moralna natura człowieka, jak i Objawienie, dlatego nie może być pomiędzy nimi zasadniczej sprzeczności. Po wtóre zaś człowiek w działaniu moralnym nie jest bynajmniej całkowicie niezależny: w swych decyzjach moralnych jest związany objawioną wolą Bożą i musi się jej podporządkować.

\footnotetext{
32 Nachf. Chr., 16.

33 Nachf. Chr., 18 n.
} 


\section{Metoda katolickiej nauki moralnej}

Z pojęciem nauki wiąże się nierozerwalnie pojęcie metody ${ }^{34}$. Chcąc poznać właściwą jej naturę, nie wystarczy wiedzieć, z jakich źródeł czerpie ona swoje poznanie. Trzeba także wiedzieć, jaką w tym celu posługuje się metodą. Szkicując tillmannowski obraz nauki moralnej, nie sposób więc pomijać to zagadnienie.

Naprzód autor wyraźnie stwierdza, że każda nauka ma właściwą sobie metodę pracy. Istnieją bowiem różne metody naukowe, a ta ich różnorodność uzależniona jest od opracowywanego materiału. I tak np. nauki humanistyczne posługują się inną metodą niż nauki przyrodnicze. Również i katolicka nauka moralna ma właściwą sobie metodę naukową, z pomocą której podchodzi do swych źródeł i wydobywa z nich swoje twierdzenia. Zdaniem F. Tillmanna jej metoda musi być mieszana. Znaczy to, że winna być tego rodzaju metodą, która „może sprostać wymaganiom nie tylko nauki, lecz także życia". Konieczność posłużenia się taką właśnie metodą wynika ze specyficznego charakteru nauki moralnej. Ten swoisty charakter wyraża się zaś w tym, że nie jest ona czysto teoretyczną nauką, gdyż — jak powiada autor — ,jest zwrócona ku życiu i dlań przeznaczona”. Innymi słowy, jest ona „praktyçną nauką, jest wydobywaniem i określaniem norm dla dokonującego się w życiu działania" ${ }^{35}$.

Po stwierdzeniu, iż rozróżnia się metodę pozytywno-spekulatywną i metodą kazuistyczną, moralista nasz podaje bliższą ich charakterystykę. Metodzie pozytywno-spekulatywnej właściwe są szczególnie dwie cechy. Naprzód to, że przedmiotem jej zainteresowań jest element zasadniczy chrześcijańskiego życia moralnego. W rozumieniu F. Tillmanna metoda ta bowiem jest skierowana ku temu co zasadnicze i zmierza do tego, by w całości chrześcijańskiego życia moralnego jak i w jego wewnętrznych powiązaniach ująć i systematycznie przedstawić ten właśnie element zasadniczy. Drugą cechą metody pozytywno-spekulatywnej jest to, że uwzględnia ona całość chrześcijańskiego życia moralnego. W przeciwieństwie do metody pozytywno-spekulatywnej metoda kazuistyczna interesuje się poszczególnym przypadkiem, starając się go rozwiązać i ocenić W oparciu o chrześcijańskie normy moralne.

Z kolei nasuwa się pytanie, za którą z tych metod i dlaczego opowiada się autor. Nasz moralista jest przekonany, iż z podanej przez niego definicji katolickiej nauki moralnej z wewnętrzną logiką wynika, że ,,jej metoda musi być przede wszystkim i głównie pozytywno-spekulatywna" ${ }^{36}$. Na innym miejscu jeszcze mocniej akcentuje on prymat tej metody stwierdzając, iż w świetle tego, co zostało powiedziane o istocie ka-

\footnotetext{
34 Różycki I., Dogmatyka. T. I: Metodologia, Kraków 1947, 21 n.

35 Nachf. Chr., 13.

36 Nachf. Chr., 13.
} 
tolickiej nauki moralnej, jest jasne, że jej metodą może być tylko metoda pozytywno-spekulatywna, a nie metoda kazuistyczna gubiąca się w poszczególnych przypadkach i w sferze grzechu ${ }^{37}$.

Jak F. Tillmann uzasadnia swoje stanowisko w tym względzie? Jego zdaniem tylko metoda pozytywno-spekulatywna, zgodnie z podaną wyżej definicją, może ogarnąć całość i zawartą w niej różnorodność życia moralnego. Jedynie ona jest w stanie zrozumieć je w jego żywej zależności od działającego człowieka i ocenić wedle ducha Chrystusowego. Nie ma natomiast takiej kazuistyki, która mogłaby wyczerpać kiedykolwiek pełnię rzeczywistego życia. Po wtóre zaś nawet jej ocena poszczególnego przypadku nie jest wystarczająca. Zanim bowiem podda go wartościowaniu moralnemu, musi wpierw wyrwać go z nurtu życia, wyłączyć z życiowego związku z konkretną sytuacją i z określonym człowiekiem. Kazuistyczne rozstrzygnięcie zawsze może być tylko warunkowe, nie może być niczym innym jak pewną wskazówką. Jest ono bowiem związane $\mathrm{z}$ założonym z góry stanem rzeczy i musi w dużej mierze pomijać indywidualne uwarunkowanie każdego działania moralnego ${ }^{38}$.

Chcąc mieć pełny obraz teologii moralnej F. Tillmanna, trzeba jeszcze nieco dokładniej przedstawić zagadnienie metody kazuistycznej. Jakie miejsce w swej teologii moralnej wyznacza on tej metodzie? Naprzód nasuwa się spostrzeżenie, że stanowisko autora $\mathrm{w}$ tym względzie nie jest jednolite. W „Die Idee der Nachfolge Christi” twierdzi on, że metoda katolickiej nauki moralnej winna być w pierwszym rzędzie pozytywno-spekulatywna. Wprawdzie metoda kazuistyczna zaszkodziła ukształtowaniu i rozwojowi teologii moralnej oraz nadała jej jednostronny kierunek, niemniej zasadnicze jej odrzucenie i wyłączenie $\mathrm{z}$ naukowego wykładu tej dyscypliny byłoby nieusprawiedliwione. Przeciwnie, nie należy odmawiać jej prawa i miejsca, które oczywiście może być tylko podporządkowane i pomocnicze. Ta jej rola wyraża się zaś w tym, że pokazując i objaśniając stosowanie chrześcijańskich norm moralnych w faktycznie zachodzących przypadkach sprawia, iż normy owe stają się bliższe życia. Z natury i przeznaczenia norm wynika, zdaniem autora, by były one bliskie życia. Przy czysto teoretycznym ich rozważaniu łatwo tracą kontakt z życiem ${ }^{39}$.

$\mathrm{Z}$ odmiennym stanowiskiem autora spotykamy się $\mathrm{w}$ jego artykule „Um eine katholische Sittenlehre”. Tu, jak o tym była mowa wyżej, stawia on tezę, że metodą katolickiej nauki moralnej może być tylko metoda pozytywno-spekulatywna, a nie metoda kazuistyczna. Kazuistykę przydziela nasz moralista teologii pastoralnej. „Tutaj - pisze on o teologii

${ }^{37} U m$ k. Sitt., 18. Metodę tę autor nazywa również ,die aufbauende Arbeitsweise”, co można przetłumaczyć przez „metoda służąca do zbudowania”.

38 Nachf. Chr., 13; Um k. Sitt., 19.

s9 Nachf. Chr., 14. 
pastoralnej - ma także swoje właściwe i naturalne miejsce oszkalowana, spowiednikowi w pewnym zakresie przydatna kazuistyka" ${ }^{40}$. Ale i tu musi być ona świadoma swoich granic i być stosowana z mądrą powściągliwością, by zamiast pożytku nie przynosiła raczej szkody. $\mathrm{Na}$ innym zaś miejscu tegoż artykułu nasz moralista stwierdza, że także metoda pozytywno-spekulatywna z umiarem i rozwagą chętnie posłuży się przykładem $^{41}$. Mimo tego ostatniego stwierdzenia w teologii moralnej F. Tillmanna nie spotykamy w ogóle kazuistyki.

$\mathrm{Na}$ zakończenie na szczególną wzmiankę zasługuje zadanie, jakie $\mathrm{F}$. Tillmann wyznacza metodzie pozytywno-spekulatywnej w swej teologii moralnej ${ }^{42}$. Polega ono na tym, by wychować dziecko Boże do życia w tej wolności, którą przyniósł mu Chrystus. Przez życie w Chrystusie chce ona uzdolnić i przygotować je do samodzielnego kształtowania sumienia i do osobistej odpowiedzialności. Żywi ona przy tym przekonanie, że także i współczesnego chrześcijanina wolno darzyć owym zaufaniem, jakim obdarzał św. Paweł swoich chrześcijan. Gdzie bowiem powiewa duch naśladowania, tam - zdaniem autora - jest wolność i szerokie pole działania, lecz także delikatna sumienność i bezwarunkowa wierność dziecka Bożego na zawsze związanego ze swym Ojcem niebieskim.

\section{Zagadnienie podstaw katolickiej nauki moralnej}

To, co F. Tillmann mówi na temat podstaw teologii moralnej, jest następstwem jego nauki o naturze tej dyscypliny. Zagadnienie podstaw w obu aspektach jest również najściślej związane z rolą idei naśladowania Chrystusa. Poprzez swój aspekt negatywny wiąże się ono ze sprawą wystarczalności tej idei, a w swym aspekcie pozytywnym sprowadza się po prostu do odnalezienia w nauczaniu Chrystusa idei przewodniej.

Przed katolicką nauką moralną, jako nauką opartą na wierze, staje zadanie właściwego ujęcia stosunku, w jakim pozostaje ona do wielorako z nią spokrewnionych czysto rozumowych gałęzi wiedzy, zwłaszcza takich jak etyka i psychologia. Temat ten częściowo został już poruszony wyżej przy okazji wyjaśniania pojęć nauki opartej na wierze i nauki opartej na rozumie. Tu chodzi o nieco inny aspekt tego zagadnienia, a mianowicie o odpowiedź na pytanie, czy w ramach teologii moralnej jako nauki opartej na wierze jest miejsce na czysto filozoficzną problematykę etyczną, a w szczególności czy czysto filozoficzna etyka może stanowić podstawę katolickiej teologii moralnej.

\footnotetext{
40 Um k. Sitt., 9 n.

41 Tam, 18.

42 Tam, 18, 19.
} 
Zapowiedziany tu temat zacznijmy od tillmannowskiej oceny sytuacji panującej na odcinku teologia moralna-etyka ${ }^{43}$. Nasz moralista powołuje się tutaj na opinię wybitnego, jak go określa, znawcy tych spraw J. Mausbacha. Ten zaś zmuszony był stwierdzić, iż odróżnienie katolickiej teologii moralnej jako nauki opartej na wierze od etyki jako nauki rozumowej w znacznej mierze istnieje tylko w teorii. Podejmując tę myśl, F. Tillmann jeszcze surowiej ocenia sytuację. Jego zdaniem w tradycyjnym opracowaniu doktryny moralnej spotykamy się z czymś wręcz przeciwnym: zamiast rozróżnienia mamy mieszaninę teologii moralnej, etyki, psychologii, prawa itp. W szczególności ta część, którą zwykło się nazywać moralną ogólną, a w której porusza się takie tematy, jak: cel ostateczny, działanie ludzkie, prawo, sumienie, cnota, grzech - stanowi właśnie tego rodzaju mieszaninę ${ }^{44}$. Daremną byłoby rzeczą, ubolewa nasz moralista, szukać tu tak podstawowych dla nauczania Chrystusa prawd i faktów, jak: odrodzenie, dziecięctwo Boże, doskonałość dziecka Bożego, siły nowego życia w Chrystusie.

W tym stanie rzeczy przed prawdziwie katolicką nauką moralną staje zadanie wypracowania swych podstaw („Grundlegung”) lub podstawowej części w opraciu o źródła wiary, a zwłaszcza w oparciu o doskonałe źródło, jakim jest Pismo św. Wysunięty tu postulat ma dwa aspekty. Pierwszy, nazwijmy go negatywnym, sprowadza się do wyłączenia z teologii moralnej wszelkiego nieteologicznego materiału. W ten sposób, jak utrzymuje autor, zostaje utorowana droga do ,gruntownego teologicznego uzasadnienia ze źródeł wiary", które zgodnie z przyjętą przez nas terminologią stanowi aspekt pozytywny powyższego zagadnienia. Według F. Tillmanna pytanie o treść teologicznego uzasadnienia sprowadza się do pytania o ideę przewodnią nauczania Chrystusa ${ }^{45}$. W dalszej części niniejszego opracowania będzie mowa o naśladowaniu Chrystusa jako idei przewodniej i tam też będzie przedstawiony pozytywny aspekt obecnego zagadnienia. Tu natomiast poprzestajemy na samym aspekcie negatywnym.

Autor nasz twierdzi, iż specyfika katolickiej nauki moralnej jako nauki opartej na wierze domaga się oddzielenia teologii moralnej od spokrewnionych $\mathrm{z}$ nią nauk. W imię tej specyfiki trzeba więc wyłączyć („Ausscheidung”) wszelki materiał należący do filozoficznej nauki mo-

43 Tam, 11.

44 Od dawna przyjął się zwyczaj dzielenia wykładu teologii moralnej na dwie części, mianowicie na moralną ogólną i moralną szczegółową. Autor nasz woli inne określenia. Część ogólną nazywa "Erster grundlegender Teil” albo „Grundlegung”, a część szczegółową - "Zweiter darstellender Teil" (por. np. Um. "k. Sitt., 11, 14; por. także K. Sitt., 9). Przy czym „Grundlegung” tillmannowskiej teologii moralnej, co do treści nie pokrywa się z dotychczasową moralną ogólną. Wyróżnia on dwa rodzaje "Grundlegung”: rozumowe, stanowiące „przedsionek” („Vorhalle”) teologii moralnej, i „Grundlegung” ze źródeł wiary.

45 Um k. Sitt., 12. 
ralnej lub do nauk o zbliżonej tematyce, jak psychologia, etnologia, prawo itp. Należy natomiast ograniczyć się „do tych podstawowych religijno-moralnych sądów, faktów i zadań, które jednoznacznie wyróżniają się jako chrześcijańsko-katolickie prawdy wiary" " ${ }^{46}$. Inaczej mówiąc, winno się tu poprzestać na czysto teologicznej problematyce chrześcijańskiego życia moralnego.

Wyłączenie nieteologicznego materiału z katolickiej nauki moralnej nie jest jednak dla F. Tillmanna równoznaczne $\mathrm{z}$ jego odrzuceniem. Etyka i psychologia ma stanowić „,naturalną podwalinę i przedsionek" teologii moralnej ${ }^{47}$. Zdaniem autora chodzi tu o stworzenie analogicznej sytuacji, jaka od dawna istnieje już w dogmatyce. Podobnie jak przed nauką o wierze stoi teologia fundamentalna mająca za zadanie wznieść fundament, na którym mogłaby wspierać się wiara jako „,rationabile obsequium", tak przed teologiczną nauką moralną winna stać etyka i spełniać względem niej analogiczne zadanie ${ }^{48}$. Dodajmy od razu, że tym przedsionkiem do właściwej teologii moralnej ma być swoiście pojęta etyka, która nie przestając być nauką filozoficzną przynależy jednak do teologii.

Do uznania etyki za naturalną podwalinę i przedsionek teologii moralnej uprawnia, zdaniem F. Tillmanna, w pierwszym rzędzie katolickie ujęcie wzajemnego stosunku wiary i wiedzy ${ }^{49}$. Jest nauką katolicką, że pomiędzy wiarą i wiedzą nie może być zasadniczej sprzeczności, wszak jedna i druga pochodzi z tego samego źródła, którym jest prawda Boża. Można więc powiedzieć, utrzymuje autor, że nie tylko wiara, lecz również i wiedza od samych swych początków posiada odniesienie do Boga. To ogólne twierdzenie jest prawdziwe także w odniesieniu do przypadku szczególowego, jakim jest wzajemny stosunek etyki i teologii moralnej. Nauki te nie tylko nie wykluczają się, co więcej - ,z góry dany jest pozytywny stosunek etyki do moralnej". Rozważanie z wiarą nad Bogiem i światem w niczym nie narusza właściwych funkcji wiedzy. Nawet religia objawiona zakłada już uznanie pewnych prawd dostępnych naturalnemu rozumowi i jego sile poznawczej, zanim jeszcze może domagać się przyzwolenia wiary i nakładać religijno-moralne zobowiązanie do tego rodzaju przyzwolenia. Podstawowe twierdzenie teologii katolickiej, iż łaska zakłada naturę, odnosi się nie tylko do dogmatyki, lecz z równą koniecznością i do moralnej, aczkolwiek w inny sposób z uwagi na specy-

46 Tam, 11; por. też Nachf. Chr., Przedm. i 20, 36.

47 Nachf. Chr., Przedm. Pohle-Gierens w swej Dogmatyce nadaje teologii fundamentalnej również miano ,przedsionka (Vorhalle)" do właściwej dogmatyki. Por. Hadrossek P., Die Bedeutung des Systemgedankens für die Moraltheologie in Deutschland seit der Thomas-Renaissance, K. Zink Verlag München 1950, 321.

48 Um k. Sitt., 11; Nachf. Chr., 21, 24 n.

49 Nachf. Chr., 24; Um k. Sitt., 11. 
fikę tej ostatniej. Jednym słowem, ze względu na faktyczny stan rzeczy nie można teologii moralnej pozbawiać naturalnego ugruntowania nadprzyrodzonego życia moralnego. Naturalny przedsionek teologii moralnej nie sposób pomijać także $\mathrm{z}$ uwagi na postulat naukowości. Stwierdza to wyraźnie nasz moralista, gdy pisze, iż ,naukowa budowa katolickiej doktryny moralnej domaga się również rozumowego ugruntowania" ${ }^{50}$.

To naturalne ugruntowanie teologii moralnej ma stanowić $\mathrm{w}$ pierwszym rzędzie specyficznie pojęta etyka, która jest etyką ,,z wiary”, jest nie „przed" moralną, lecz „wewnątrz" niej, nie przestając jednak być nauką filozoficzną. Przede wszystkim autor zastrzega się, że nie może to być absolutnie tzw. etyka niezależna. Etyka ta, jak była już o tym mowa, na wszelkie sposoby usiłuje nie brać pod uwagę Boga i Jego postępowania $\mathrm{z}$ człowiekiem $\mathrm{w}$ porządku natury i łaski, stworzenia i objawienia. Etyka jako naturalne ugruntowanie moralnej musi być pod pewnym względem podobna do teologii fundamentalnej. Ta zaś jest teologią z tej racji, że w już istniejącej wierze stara się pokazać fundamenty, zna tę wiarę i ze względu na nią zakłada fundamenty. Również i etyka mająca stanowić przedsionek i naturalną podwalinę katolickiej nauki moralnej nie może być etyką czystego rozumu, gdyż już wie o moralnej i ze względu na nią stara się wypełnić swoje zadanie odnośnie do życia i postępowania moralnego. Etyka, o jaką tu chodzi, w równej mierze jak teologia fundamentalna przynależy, zdaniem F. Tillmanna, do teologii. Człowieka, przedmiot swych zainteresowań, widzi więc ona ,zawsze już w świetle wiary i zwraca się do naturalnego człowieka, który istnieje tylko w całości przyrodzonego i nadprzyrodzonego bytu ludzkiego". Jej zadaniem jest „,w całym człowieku, o którym traktuje moralna, odkryć jedną stronę, naturalną, która jest i pozostaje włączona w całość" ${ }^{51}$.

Staranne rozróżnienie pomiędzy nauką rozumową i nauką opartą na wierze ma w przekonaniu F. Tillmanna bardzo doniosłą zaletę. Umożliwia ono mianowicie stworzenie solidnej podbudowy filozoficznej, gruntowne opracowanie duchowych założeń każdego aktu moralnego, takich jak: sumienie i jego wychowywanie, wolność woli i tak liczne jej ograniczenia. Kiedy natomiast, utrzymuje autor, podejmuje się beznadziejną próbę, by ten olbrzymi, ciągle rosnący materiał, który przecież i katolicka nauka moralna musi brać pod uwagę, włączyć w jej wykład, to albo wypada się z jej ram, albo grzęźnie w nieodpowiedzialnym, powierzchownym ujmowaniu spraw moralnych ${ }^{52}$.

50 Um k. Sitt., $11 \mathrm{n}$.

51 Nachf. Chr., 26.

52 Um k. Sitt., $11 \mathrm{n}$. 


\section{Katolicka nauka moralna - nauką normatywną}

Określiliśmy wyżej stosunek katolickiej nauki moralnej do wielorako z nią spokrewnionych nauk czysto rozumowych. Z kolei nasuwa się pytanie, jakie jest miejsce doktryny moralnej Kościoła wśród dyscyplin teologicznych. Katolicka nauka moralna, jak o tym była mowa, jest nauką teologiczną. A teologia obejmuje zarówno nauki spekulatywne, jak i praktyczne ${ }^{53}$. Chcąc więc pokazać tillmannowski obraz teologii moralnej w ogólności, trzeba zapytać, do której z tych dwóch grup nauk teologicznych ona przynależy.

Zadaniem każdej nauki moralnej, utrzymuje F. Tillmann, jest określić prawa odnoszące się do przyszłego postępowania człowieka. Inaczej mówiąc, pyta ona nie o to, co jest lub co było, lecz o to, co powinno być. Jest zatem nauką normatywną (,Normwissenschaft") ${ }^{54}$.

To samo, zdaniem autora, trzeba powiedzieć i o teologii moralnej: ona również jest nauką normatywną ${ }^{55}$. Interesuje ją powinność, a nie czysty byt. Jej przedmiotem jest powinność, która wyznacza ludzkie postępowanie i dostosowuje je do moralnie wartościowych celów. $\mathrm{Na}$ innym miejscu moralista nasz stwierdza, iż katolicka doktryna moralna nie jest bynajmniej czysto teoretyczną nauką. Wprost przeciwnie, jest praktyczną nauką w tym znaczeniu, że wypracowuje i określa normy działania ${ }^{56}$.

Mając na uwadze normatywność, F. Tillmann podkreśla znạmienną różnicę pomiędzy etyką a teologią moralną. Ta ostatnia podaje normy etyczne, prawa moralne i wymagania, które są miarodajne dla kształtowania życia człowieka wierzącego i wiążące w sumieniu. Norm tych nie czerpie ona jednak z czystego rozumu lub z analizy świadomości moralnej. Wydobywa je natomiast ze źródeł wiary katolickiej. Dzięki temu, że pochodzą one ze źródeł wiary, są one bezwzględnie prawdziwe i obowiązujące. Katolicka nauka moralna jest normowaną nauką normatywną ${ }^{57}$. Te same myśli podejmuje autor w swym artykule „Um eine katholische Sittenlehre". Stwierdza tu mianowicie, że zadaniem katolickiej nauki moralnej nie jest znaleźć dopiero i udowodnić prawdę moralną jako obowiązującą zasadę życia chrześcijańskiego. Zastaje („vorfindet”) ją ona w zródłach objawionych jảko prawdę Bożą i zobowiązującą sumienie ${ }^{58}$. Tak więc wedle F. Tillmanna katolicka nauka moralna również i $\mathrm{w}$ swym wymiarze normatywnym jest nauką opartą na wierze.

53 Nachf. Chr., 20; por. też Różycki I., Dogmatyka. T. I: Metodologia, Kraków 1947,66 .

54 K. Sitt., 13, 10.

55 Nachf. Chr., 9 n.

56 Nachf. Chr., 13.

57 Nachf. Chr., 14.

58 Um k. Sitt., 10.

27 - Analecta Cracoviensia 


\section{6. Życiowy związek moralnej z dogmatyką}

Zagadnienie niniejsze jest kontynuacją poprzedniego tematu, który dotyczył miejsca katolickiej nauki moralnej. wśród pozostałych dyscyplin teologicznych. Główne źródło zła w teologii moralnej widzi F. Tillmann w tym, że usamodzielniając się, oderwała się ona od dogmatyki. Chcąc temu złu zaradzić, należałoby na powrót nawiązać życiową łączność obu dyscyplin. Wydaje się, iż cel ten zamierza autor osiągnąć z pomocą idei naśladowania Chrystusa. Pytamy zatem, dlaczego i jakie powiązania winny, zdaniem autora, zachodzić pomiędzy nauką moralną i nauką wiary.

W paragrafie poświęconym historii katolickiej nauki moralnej znajdujemy następującą charakterystykę jej potrydenckiego rozwoju: „Najważniejsze i najbardziej brzemienne w skutki zjawisko tego okresu leży w oderwaniu moralnej od dogmatyki. Odtąd ta pierwsza ukazuje się coraz częściej jako samoistna dyscyplina" ${ }^{59}$. Następstwa rozdziału były wręcz tragiczne, drogo musiała moralna zapłacić za oddzielenie się od dogmatyki. Moralista nasz mocno akcentuje szczególnie trzy zgubne skutki tego uniezależnienia się ${ }^{60}$. Rozbrat moralnej z dogmatyką ,oddzielił ją wprawdzie nie teoretycznie, ale praktycznie od doskonałego jej źródła Pisma św., a za to obciążył wielką ilością filozoficznego, prawniczego i pastoralnego materiału" ${ }^{61}$. Oderwanie od dogmatyki pociągnęło za sobą przekształcenie moralnej $\mathrm{z}$ nauki o cnocie $\mathrm{w}$ naukę o grzechu. W parze z tym rozdzieleniem szło i to, że teologia moralna coraz bardziej przybierała charakter nauki przeznaczonej dla duchownych, zwłaszcza duszpasterzy-spowiedników, przestając tym samym zwracać się do wszystkich chrześcijan.

Skoro oddzielenie moralnej od dogmatyki pociągnęło za sobą szereg zgubnych skutków, to chcąc się ich pozbyć, trzeba na nowo nawiązać łączność nauki moralnej z nauką wiary. Jednym z zamierzeń $\mathrm{F}$. Tillmanna jest właśnie przywrócenie tej więzi. W przedmowie do „Katholische Sittenlehre" pisze on, iż zawarty tu wykład nauki moralnej ,chce zabezpieczyć w budowie, jak i w przedstawieniu jej wewnętrzny i k’onieczny związek z nauką wiary, który przy usamodzielnieniu się doktryny moralnej jako odrębnej nauki teologicznej został zerwany ze szkodą dla niej" "62.

Podejście do zagadnienia stosunku moralnej i dogmatyki od strony fatalnych następstw rozdziału obu tych dyscyplin jest ujmowaniem spraw

59 Nachf. Chr., 36. Na marginesie warto dodać, że zdaniem autora nie zostało jeszcze wyjaśnione, co doprowadziło do tego oderwania się i uniezależnienia moralnej od dogmatyki.

60 Nachf. Chr., 20, 36; Um k. Sitt., 9, $16 \mathrm{nn}$.

61 Nachf. Chr., 36.

62 K. Sitt., Przedm., 5. 
od zewnątrz. Innymi słowy nie dlatego jedynie należy dążyć do przywrócenia więzi nauki moralnej z dogmatyką, że jej zerwanie jest zgubne dla moralnej. Ta potrzeba wynika przede wszystkim z wewnątrz, z samej natury tych dyscyplin, jak i teologii w ogóle. Tak wyraźnie sformułowanego twierdzenia nie znajdziemy wprawdzie u F. Tillmanna, niemniej szereg danych uprawnia do postawienia go. Naprzód autor nasz określa miejsce obu dyscyplin w teologii. „Katolicka nauka moralna - pisze on - tworzy razem z nauką wiary teologię systematyczną". I wyjaśnia od razu, iż ,ten istotny (wesensmässige) związek obu nauk teologicznych okazuje się w tym, że mają one wspólne ze sobą źródła, jak i metodę" ${ }^{63}$. Wewnętrzna łączność obu dyscyplin znalazła również swój wyraz zewnętrzny. Dokonało się to w scholastyce, która - podkreśla F. Tillmann - po raz pierwszy ujęła i przedstawiła ją w sposób naukowy i systematyczny. To stwierdzenie daje autorowi sposobność do zreferowania znanej nauki św. Tomasza o jedności teologii ${ }^{64}$. Zasadniczo autor poprzestaje na samym zreferowaniu stanowiska Akwinaty. Wobec braku dowodów przeciwnych można przyjąć, że przynajmniej teoretycznie je podziela.

Podkreślając wewnętrzny, istotny związek obu dyscyplin F. Tillmann nie traci $z$ oczu istniejącej między nimi różnicy. Widoczna jest ona naprzód w przedmiocie. Dogmatyka zajmuje się bowiem istotą i działaniem Boga rozpatrując je w nich samych. Natomiast przedmiot nauki moralnej stanowi ludzkie życia i działanie, o ile jego życiowym podłożem i celem jest Bóg, i o ile przez odkupienie i łaskę wznosi się ono ku Niemu. Dogmatyka to ,doctrina credendorum”, moralna — „doctrina faciendorum". Autor podkreśla także, iż z innego punktu widzenia obie te dyscypliny patrzą na samego człowieka. W dogmatyce ukazuje się człowiek jako ten, którego ukształtowała wola Boga i którego dźwiga Jego łaska. Moralna zaś widzi go w jego wolności i odpowiedzialności. Odmienne jest także ich spojrzenie na Chrystusa. Ta pierwsza przedstawia Go jako naszego Odkupiciela i Pośrednika, druga - jako nasz Wzór i Cel naszej wspólnoty z Bogiem ${ }^{65}$.

Zostało wyżej wspomniane, że F. Tillmann w swym wykładzie nauki moralnej chce zachować ,wewnętrzny i konieczny związek z nauką wiary”. Z drugiej strony, jak co dopiero była o tym mowa, jest świadom odrębności obu tych dyscyplin. A nawet zarzuca J. B. Hirscherowi, iż w jego moralnej ,element czysto dogmatyczny nie jest wystarczająco oddzielony od nauki moralnej" 66 . Przed naszym moralistą staje więc zada-

\footnotetext{
${ }^{63}$ Nachf. Chr., 20.

${ }^{64}$ Nachf. Chr., 20.

${ }_{65}$ Tam, 20.

66 Tam, 43.
} 
nie utrzymania życiowego związku moralnej z dogmatyką przy równoczesnym wyodrębnieniu pierwiastka czysto dogmatycznego.

\section{Nauka dla wszystkich chrześcijan}

Jak wspomniano wyżej, F. Tillmann utrzymuje, iż od Soboru Trydenckiego, od chwili usamodzielnienia się i zerwania życiowego związku z dogmatyką rozwój teologii moralnej przybrał na wskroś jednostronny kierunek. Ta jednokierunkowość uwidoczniła się naprzód w zmianie adresata. Nauka moralna przestała być adresowana do wszystkich chrześcijan, a niemal wyłącznym jej adresatem stał się duszpasterz, w szczególności zaś spowiednik. Moralna przybrała postać podręcznika dla duchownych, narzędzia do sprawowania sakramentu pokuty ${ }^{67}$. Autor widzi dwa ujemne skutki owego jednostronnego rozwoju doktryny moralnej. „Pierwszym następstwem - pisze on - było to, że podręczniki teologii moralnej stały się dla zwykłych chrześcijan po prostu niestrawne" ${ }^{68}$. Wprawdzie - przyznaje nasz moralista - wciąż ukazuje się wiele podręczników, a jednak gdy nieteolog - nie mówiąc już o niekatoliku zapyta o książkę, która mogłaby go pouczyć o katolickiej postawie życiowej, jej celach i wymaganiach, doznaje się nieprzyjemnego zakłopotania. Dlaczego? Czy z uwagi na trudny specyficzny język? W oparciu o dalsze wypowiedzi autora trzeba raczej stwierdzić, iż chodzi mu przede wszystkim o treść owych podręczników. Jego zdaniem jest znamienne, że wszystkie te podręczniki w ogóle nie myślą o tym, by dać w duchu Chrystusa wprowadzenie do zobowiązania nałożonego każdemu z Jego uczniów. Ich cel jest w całości, jak i w szczegółach przykrojony do działalności duszpasterza i kierownika sumienia czy to $\mathrm{w}$ konfesjonale, czy poza nim. Niewiele wyczuwa się tu z wzniosłej wielkości i imponującego piękna zadania życiowego nałożonego wszystkim chrześcijanom; za to tym więcej mówi się o sprzeniewierzeniu się mu i o grzechu. A przecież nie można, utrzymuje F. Tillmann, kwestionować tego, że znajomość nauki moralnej, tak samo jak znajomość nauki wiary, jest największym i najważniejszym życzeniem katolika. Jest mu równie konieczna jak powietrze, którym oddycha, i jak codzienny chleb, bez którego nie może żyć. I dlatego pierwszy metodyczny postulat wysunięty pod adresem katolickiej nauki moralnej powiada, iż winna ona wyzwolić się ze swego zubożenia i na powrót stać się wspólnym dobrem dzieci Bożych, które zostały powołane do doskonałości chrześcíjańskiej i których zadaniem jest jej realizacja w życiu ${ }^{69}$.

${ }^{67}$ Um k. Sitt., 9, 16; por. też Nachf. Chr., 20, 36.

68 Um k. Sitt., 16.

${ }^{69} \mathrm{Tam}, 17$. Przedstawione tu stanowisko F. Tillmanna wobec podręczników dla 
Jak wspomnieliśmy wyżej, „niestrawność dla prostych chrześcijan” podręczników teologii moralnej sprowadza nasz autor zasadniczo do ich treści ściśle uzależnionej od przyświecającego im celu, którym jest służyć duszpasterzowi-spowiednikowi. Nie lekceważy on oczywiście sprawy języka, skoro w podtytule swego dzieła „Der Meister ruft” daje wyjaśnienie: „Katolicka nauka moralności przedstawiona zrozumiale dla wszystkich". A w przedmowie do pierwszego wydania tego dzieła pisze: „Ta książka jest przeznaczona dla chrześcijan laików. Przynosi ona w popularnym przedstawieniu treść mego większego dzieła (...) i pomija fachową, naukowo-teologiczną terminologię" "70.

\section{Teologia moralna $\mathrm{w}$ pierwszym rzędzie nauką o cnocie}

Teologia moralna $\mathrm{w}$ przekonaniu naszego autora winna dać pozytywny wykład chrześcijańskiego życ̀ia moralnego. Innymi słowy winna dać jego ujęcie od strony cnoty, ideału, doskonałości, a nie od strony grzechu. Chrystus wzywając do naśladowania, wzywa do osiągnięcia tej doskonałości, której wzorem jest zarówno Bóg Ojciec, jak i On sam. Treść idei naśladowania Chrystusa jest więc na wskroś pozytywna.

Zerwanie życiowego związku z dogmatyką i jednostronny rozwój pod kątem potrzeb duszpasterza-spowiednika sprawiły, że moralna katolicka $\mathrm{z}$ nauki o cnocie przekształciła się $\mathrm{w}$ naukę o grzechu ${ }^{71}$. To przesunięcie punktu ciężkości w stronę grzechu znalazło swój wyraz w podręcznikach teologii moralnej w tym, że na plan pierwszy wysunął się w nich właśnie grzech. Wyraźnie stwierdza to autor pisząc, iż „zamiast głoszonej przez Chrystusa i od wszystkich wierzących wymaganej doskonalszej sprawiedliwości, która winna stanowić jej (tzn. moralnej) naturalny i właściwy przedmiot, na plan pierwszy wysunęło się jej (tzn. doskonałości) zaprzeczenie i zniweczenie, mianowicie grzech; a cnota - to co jedynie konieczne i twórcze - w znacznej mierze została zepchnięta na dalszy plan" ${ }^{72}$. O tej pierwszoplanowości grzechu można się przekonać porównując np. ilość stron poświęconych cnocie i przeciwnym jej grzechom. Rachunek

duszpasterzy-spowiedników nie jest równoznaczne $\mathrm{z}$ bezwzględnym odrzuceniem tych podręczników. Stwiendza on bowiem wyraźnie: „Nie ulega wątpliwości, że spowiednik potrzebuje specjalnego wprowadzenia a także odpowiednich podręczników. Ale to jest zadaniem osobnej gałęzi wiedzy teologicznej, która w toku rozwoju znalazła coraz obszerniejsze i donioślejsze miejsce w budowie całej teologii oraz w nauce przyszłych kapłanów" (tam, 9). Inaczej mówiąc przeznaczone dla kapłanów podręczniki duszpasterstwa trzeba nazwać po imieniu i ,wyłączyć z naukowej budowy katolickiej doktryny moralnej, do której one nie należą" (tam, 17).

70 Tillmann F., Der Meister ruft. Die katholische Sittenlehre gemeinverständlich dargestellt. Patmos Verlag Düsseldorf 1948, 6. Odtąd dzieło to będzie cytowane w skrócie: Meister ruft.

71 Nachf. Chr., 20, 36; Um k. Sitt., 17.

72 Um k. Sitt., 9. 
zdecydowanie wypada na niekorzyść tej pierwszej. Autor wșpomina o takim przypadku, w którym stosunek ten wyraża się cyframi $11: 130$. Nie tylko strona ilościowa świadczy o prymacie grzechu w podręcznikach moralnej. Wspomniane wyżej przekształcenie się moralnej z nauki o cnocie sięgnęło głębiej ${ }^{73}$. Św. Tomasz ujmował naukę moralną w jej organicznym związku z nauką wiary i wedle schematu cnót. Tymczasem potrydencki jej rozwój poszedł w kierunku wykładu według Dekalogu. Może nie byłoby to tak dalece zgubne dla moralnej, gdyby nie fakt, że samo negatywne podejście do większości przykazań przesunęło zdecydowanie punkt ciężkości w stronę grzechu, wychodząc tym samym naprzeciw żądaniu większej przydatności dla spowiednika. Za przykład negatywnego podejścia do przykazań niech posłuży za F. Tillmannem choćby to, że przy ósmym przykazaniu szeroko rozprawia się o wszystkich rodzajach nieprawdy, podczas gdy umiłowanie prawdy i cnota szczerości - mające zasadnicze znaczenie dla życia prowadzonego w duchu Chrystusa - są zaledwie wspomniane. Jest to tym boleśniejsze, że ów prymat grzechu dostrzega się nie tylko w konkretnym ukształtowaniu moralnej, lecz także w tym, co można by nazwać jej teorią. F. Tillmann tecto nomine wspomina o czołowym moraliście, który nie zarumieniwszy się nawet ,postawił twierdzenie, że ta święta nauka bardziej obraca się koło grzechu niż wokół cnoty" 74 .

Negatywnego ustosunkowania się naszego autora do tego rodzaju podręczników teologii moralnej nie można interpretować $\mathrm{w}$ tym sensie, jakoby chciał on wyeliminować z nich naukę o grzechu. Wyraźnie odcina się on od tego rodzaju tendencji. Jest dla niego rzeczą oczywistą, że katolicka nauka moralna nie może pomijać faktu grzechu i jego niszczycielskiej mocy. Owszem, fakt ten winien znaleźć w niej należne mu - ale bynajmniej nie pierwsze - miejsce $^{75}$.

Powyższe uwagi doprowadzają F. Tillmanna do wniosku, iż drugi metodyczny postulat, jaki trzeba postawić katolickiej nauce moralnej, głosi, że „musi być ona w pierwszym rzędzie nauką o cnocie" ${ }^{76}$. Wzniosłym jej zadaniem jest pokazać bogactwo i piękno cnót chrześcijańskich, ich wewnętrzny związek z naśladowaniem Chrystusa i ich nieodzowność dla tego naśladowania. Jeśli ma pokazać bogactwo cnót, to - zdaniem autora - nie może ona pomijać lub wspominać tylko mimochodem, jak to czyni wiele podręczników, szeregu istotnych cnót chrześcijańskich, takich jak głęboka cześć, pobożność czy pracowitość.

Do zagadnienia pozytywnej treści katolickiej nauki moralnej podcho-

73 Nachf. Chr., 36; Um k. Sitt., 17.

74 Um k. Sitt., 9.

75 Tam. 17.

76 Tam, 18; K. Sitt., 5 (Przedm.). 
dzi autor także od strony ideału. Twierdzi mianowicie, iż jej zadaniem jest przedstawić i uzasadnić katolicki ideał życia ${ }^{77}$. W szczególności zaś winna ona pokazać ideał osobowości chrześcijańskiej w jej imponującym pięknie i wielkości ${ }^{78}$.

$\mathrm{Na}$ szczególne podkreślenie zasługuje tu jeszcze ściśle $\mathrm{z}$ omawianym tematem związane zagadnienie ascetyki i mistyki ${ }^{79}$. To, że zostały one wyłączone z wykładu moralnej i przekazane odrębnej gałęzi wiedzy, jest dla F. Tillmanna dalszym zubożeniem nauki moralnej. Jeśli jednak utrzymuje on - weźmie się na serio twierdzenie, że zadaniem doktryny moralnej jest przedstawienie powszechnie obowiązujących norm dążenia do doskonałości chrześcijańskiej, wówczas nie może być wątpliwości, że ascetyka i mistyka stanowią. nieodzowną część składową tej dyscypliny. Ich konieczność i znaczenie unaocznia się zwłaszcza w moralnej pojętej jako nauka o naśladowaniu Chrystusa. Sam Zbawiciel ściśle związał naśladowanie Go z zaparciem się siebie: bez zaparcia się siebie nie można być Jego uczniem. Tak samo to, co we wzorze Chrystusa wzbudza zapał i stawia wymagania, może wyrastać i przynosić owoc tylko na gruncie Pawłowej mistyki chrystocentrycznej.

\section{IDEA NASLADOWANIA CHRYSTUSA W UJĘCIU F. TILLMANNA}

Z historii katolickiej teologii moralnej wiadomo, że dyscyplina ta może być rozmaicie ukształtowana, że jej wykład może być ujęty w ramach różnych systemów. Autor nasz pojmuje katolicką doktrynę moralną jako naukę o naśladowaniu Chrystusa. „Katolicka doktryna moralna - stwierdza wyraźnie F. Tillmann - jest naukowym wykładem naśladowania Chrystusa w życiu jednostkowym jak i społecznym" "80. Poszukując odpowiedzi na pytanie, jaką rolę spełnia naśladowanie Chrystusa w tillmarnowskim wykładzie teologii moralnej, trzeba z kolei ustalić treść oznaczoną przez autora słowem „Nachfolge Christi" ${ }^{81}$. Jak wiadomo, na idei naśladowania m. in. Max Scheler oparł swój system etyczny, ale idei tej nie zaczerpnął on z Pisma św. Natomiast F. Tillmann ideę podstawową lub przewodnią do swego wykładu teologii moralnej chce znaleźć w nauczaniu Chrystusa. Taką właśnie ideą jest dla naszego moralisty idea na-

77 Nachf. Chr., Przedm.

${ }^{78}$ K. Sitt., 5 (Przedm.).

${ }^{79}$ Nachf. Chr., 21; Um k. Sitt., 18.

${ }^{80}$ Nachf. Chr., 9, 21; K. Sitt., 9.

${ }^{81}$ Niektórzy teolodzy jak np. K. Hörmann (Nachfolge Christi, w Lexikon der christlichen Moral, Tyrolia Verlag Innsbruck Wien München 1969, 849-852) czy R. Hofmann (Moraltheologische Erkenntnis- und Methodenlehre, M. Hueber Verlag München 1963, 253 nn.) rozróżniają pomiędzy „Nachfolge” i „Nachahmung”. Przy czym ich zdaniem „Nachahmung” jest etycznym aspektem „Nachfolge”. F. Tillmann odróżnia tylko „echte Nachfolge” od „blosse Nachahmung”. 
Śladowania Chrystusa ${ }^{82}$. Ideę tę przeto trzeba brać w biblijnym wymiarze, czyli tak jak ją F. Tillmann wydobywa z Pisma św. A ten wymiar, jak zobaczymy, jest szerszy od czysto etycznego wymiaru idei naśladowania.

\section{Religijny (ontyczny) aspekt naśladowania Chrystusa}

Mianem tym chcemy tu oznaczyć przede wszystkim pewne nadprzyrodzone fakty życia chrześcijańskiego będące źródłem możliwości i zobowiązania do naśladowania Chrystusa. „Ostateczna podstawa możliwości starania się o naśladowanie Chrystusa, pisze F. Tillmann, leży w mistycznym fakcie życia w Chrystusie, w które uczeń jest włączony od chwili chrztu" 83. W uporządkowaniu siedmiu sakramentów św. można, zdaniem autora, stawiać na pierwszym miejscu kapłaństwo lub chrzest w zależności od punktu widzenia, którym jest albo życie społeczne w Królestwie Bożym, albo życie jednostkowe dziecka Bożego. Teolog nasz sądzi, że w katolickiej nauce moralnej pierwszeństwo należy przyznać temu ujęciu, które na czele sakramentów stawia chrzest, a to z tej racji, że ,dopiero wraz z chrztem udzielone zostaje nadprzyrodzone życie, z którego wewnętrznie i koniecznie wynika zobowiązanie do naśladowania Chrystusa" ${ }^{84}$. Na zakończenie swych rozważań o jedności elementu religijnego i moralnego w życiu chrześcijańskim autor pisze: „Trzeba tu znowu przypomnieć, że podstawowe fakty nowego życia, jakie darowane zostało wierzącemu, a mianowicie dziecięctwo Boże, wspólnota z Chrystusem, Duch Święty, choć tak bardzo leżą na płaszczyźnie wiary religijnej, jednocześnie i koniecznie oznaczają najmocniejsze (stärkste) zadanie i zobowiązanie" ${ }^{85}$.

W związku z powyższymi stwierdzeniami nasuwa się pytanie, czy ta nadprzyrodzona rzeczywistość stanowiąca źródło możliwości i zobowiązania do naśladowania Chrystusa może być zaliczona do tych treści, które F. Tillmann obejmuje słowem „Nachfolge Christi”. Na temat roli roku kościelnego czytamy u naszego moralisty: „Tak więc rok kościelny chce pouczyć chrześcijanina, by naśladował Tego, który przewodzi mu w wierze i ją wydoskonala, by wchłonął w siebie Jego życie i wedle swych sił przedstawił je w sobie" ${ }^{86}$. W świetle zacytowanego tu zdania naśladowa-

82 Um k. Sitt., 12, 13.

83 Nachf. Chr., 57.

84 Tillmann F., Handbuch der katholischen Sittenlehre. Bd IV/2: Die Verwirklichung der Nachfolge Christi, Patmos Verlag Disseldorf 1950, 185. Odtąd dzieło to będzie cytorwane w skrócie: Verwirklichung Nachf. Chr. II.

85 Nachf. Chr., 141.

${ }^{86}$ Tillmann F., Handbuch der katholischen Sittenlehre. Bd IV/1: Die Verwirklichung der Nachfolge Christi, Patmos Verlag Düsseldorf 1950, 246. Odtąd dzieło to będzie cytowane w skrócie: Verwirklichung Nachf. Chr., I. 
nie Chrystusa jest naprzód przyjęciem Jego życia, a więc nadprzyrodzonej rzeczywistości, która następnie ma się okazać na zewnątrz w odpowiednim postępowaniu. O Eucharystii pisze autor: „W tym sakramencie - jest to najwyższym spełnieniem jego znaczenia - naśladowanie Chrystusa winno być urzeczywistnione aż do całkowitego stania się jedno z Nim. (...) Jeśli jednak to stanie się jedno $\mathrm{z}$ Nim ma być prawdą, musi ono znaleźć swój żywy wyraz w całej postawie życiowej chrześcijanina: w jego pobożności (...), w jego myśleniu, chceniu i działaniu” ${ }^{87}$. „Stanie się jedno" z Chrystusem oznacza tu nadprzyrodzoną rzeczywistość zapoczątkowaną przez chrzest a w Eucharystii osiągającą swoją pełnię. W parze z tym „staniem się jedno" w porządku ontycznym musi iść „stanie się jedno" w porządku etycznym. Skoro zadaniem Eucharystii jest doprowadzić naśladowanie Chrystusa do całkowitego "stania się jedno z Nim" i skoro to obejmuje zarówno porządek ontyczny jak i etyczny, trzeba powiedzieć, że w słowie naśladowanie Chrystusa F. Tillmann widzi wspólną nazwę tych dwóch rzeczywistości.

Jak wspomniano wyżej, autor w nauczaniu Chrystusa chce znalezć ideę podstawową lub przewodnią. Dziwne wydaje się mu to, że teologia moralna wykorzystała ideę Królestwa Bożego, a nie dostrzegła innej idei podstawowej, „która wprost domaga się religijno-moralnego życia Jego uczniów i także w po-ewangelicznym przepowiadaniu w świecie grecko-rzymskim wywarła najsilniejszy wpływ”. I dalej wyjaśnia, że „ma na myśli ideę naśladowania, w której byt i powinność, wzór i jego odtworzenie (Nachbild) zaznaczają się niezrównanie i bardzo żywo, jak tego potrzebuje nauka morałna" ${ }^{88}$. W obecnym kontekście w zacytowanym zdaniu trzeba szczególnie zaakcentować tillmannowską tezę, że w idei naśladowania Chrystusa „zaznaczają się byt i powinność”, lub - jak na innym miejscu powiada autor - łączą się z sobą. Inaczej mówiąc, idea naśladowania Chrystusa $\mathrm{w}$ ujęciu naszego moralisty obejmuje byt, w tym wypadku pewną nadprzyrodzoną rzeczywistość, oraz powinność wyłaniającą się $\mathrm{z}$ tej nadprzyrodzonej rzeczywistości. Takie stawianie spraw przez F. Tillmanna uprawnia do rozumienia religijnego aspektu naśladowania Chrystusa tak, jak to zostało określone na początku obecnych rozważań.

Ta nadprzyrodzona rzeczywistość, którą mamy na myśli mówiąc o religijnym aspekcie naśladowania Chrystusa, jest związana z porządkiem bytowania. Dla chrześcijanina oznacza ona bowiem zapoczątkowanie nowego sposobu bytowania $\mathrm{w}$ najściślejszym zespoleniu z Chrystusem. I dlatego tę nową rzeczywistość można by także nazwać nadprzyrodzoną ontologią chrześcijańskiego życia moralnego lub aspektem ontycznym na-

87 Verwirklichung Nachf. Chr., II, 223.

88 Um k. Sitt., 13. 
śladowania Chrystusa ${ }^{89}$. Wolno ją również nazwać aspektem sakramentalnym naśladowania Chrystusa ${ }^{90}$. W obecnym bowiem porządku zbawczym rzeczywistość tę sprawiają z zasady sakramenty św.

Ustaliwszy w ten sposób terminologię, chcemy z kolei zająć się treścią religijnego aspektu naśladowania Chrystusa, a więc tymi podstawowymi nadprzyrodzonymi faktami życia chrześcijańskiego, które stanowią źródło możliwości i zobowiązania do naśladowania Chrystusa. Fakty te różnie są określane w języku Pisma św. Tilmannowska moralna naśladowania Chrystusa nie tylko czerpie swoją treść z Pisma św., lecz także.w dużej mierze posługuje się jego obrazowym językiem. Tak np. autor stwierdza, że również pierwotne chrześcijaństwo pojmowało religijno-moralne zadanie człowieka wierzącego jako naśladowanie Chrystusa. W przytoczonych na dowód tej tezy tekstach nie ma słowa naśladowanie, jest natomiast mowa o ,życiu w Chrystusie" czy też o ,przyoblekaniu się w Chrystusa" " ${ }^{1}$. Chcąc zatem poznać treść idei naśladowania Chrystusa, trzeba wprzód poznać treść zawartą w tych różnych określeniach, ich wzajemny związek, jak również ich związek z naśladowaniem. Z uwagi na znaczenie tych nadprzyrodzonych faktów dla naśladowania Chrystusa F. Tillmann mówi o takich, które stanowią nadprzyrodzoną podstawę naśladowania Chrystusa, i o takich, które są jego nadprzyrodzonymi siła$\mathrm{mi}^{92}$.

A. Nadprzyrodzona podstawa naśladowanlia Chrystusa

Nadprzyrodzoną podstawę naśladowania Chrystusa widzi F. Tillmann w tym, co Pismo ș́w. nazywa ,narodzeniem z Boga” lub „nowym 'stworzeniem".

\section{a. Narodzenie $z$ Boga lub odrodzenie 93}

Na początku każdego chrześcijańskiego bytu i życia, utrzymuje autor, stoi to zdarzenie, które św. Jan obrazowo nazywa „zrodzeniem z Boga" lub ,odrodzeniem”. Przede wszystkim nocna rozmowa Chrystusa z Nikodemem $(\mathrm{J} 3,1 \mathrm{nn})$ poświęcona jest zagadnieniu zaistnienia w człowieku nowego, nadprzyrodzonego życia. Narodzenie się na nowo dokonuje się z wody i Ducha, czyli w chrzcie. Chrystus wskazuje tu również na konieczność odrodzenia opierając się na ogólnym twierdzeniu, iż owoc poczęcia dokładnie odpowiada zasadzie poczynającej. Podobnie jak natural-

${ }^{89}$ Nachf. Chr., 105.

90 Tam, 55.

91 Tam, 11.

92 Tam, $84 \mathrm{nn} ; K$. Sitt., $32 \mathrm{n}$; Meister ruft, $20 \mathrm{nn}$. Autor mówi tu o nadprzyrodzonej podstawie $i$ siłach naśladowania Chrystusa, osobowości chrześci jańskiej, dziecięctwa Bożego. Osobowość chrześcijańska-lub dziecięctwo Boże są zadaniem naśladowania Chrystusa.

${ }_{93}$ Nachf. Chr., $85 \mathrm{nn} ;$ K. Sitt., 32; Meister ruft, $20 \mathrm{nn}$. 
ne życie człowieka wywodzi się z naturalnej zasady życia, tak jego życie nadprzyrodzone musi mieć nadprzyrodzoną zasadę życia.

Jaka treść, zdaniem naszego moralisty, zawiera się w Janowym ,zrodzeniu z Boga"? ${ }^{94}$ Powtórne narodzenie, analogicznie do naturalnych narodzin, oznacza zapoczątkowanie nowej formy istnienia (,Daseinsform”), wyższego, nadprzyrodzonego sposobu bytowania (,Seinsweise”). Stwarza w odrodzonym człowieku nowy, trwały stan i ontycznie przeobraża jego dotychczasowy stan naturalny. Nie sprowadza się ono jedynie do udzielania przez Boga nieustannej pomocy; przeciwnie - polega na przemianie, która daje człowiekowi nowy sposób bytowania. Darowanie nowego, Bożego życia nie może być oczywiście pojmowane jako udzielenie stworzeniu substancji Bożej. Niewłaściwym byłoby również chcieć rozumieć odrodzenie jako moralne odnowienie czy udoskonalenie człowieka. Moralna. odnowa jest wynikiem długiej pracy i wielu wysiłków; odrodzenie natomiast jest dziełem Boga i dokonuje się w jednej chwili. Nie wyczerpuje się ono w odpuszczeniu grzechów. Narodzenie z Boga obejmuje wprawdzie odpuszczenie grzechów, ale to odpuszczenie stanowi jedynie negatywną stronę odrodzenia. Wlanie życia nadprzyrodzonego jest bowiem wspólną przyczyną zarówno zgładzenia grzechów, jak i istotnej świętości człowieka usprawiedliwionego.

\section{b. Nowe stworzenie ${ }^{95}$}

Również i Listom św. Pawła, stwierdza F. Tillmann, nie obce jest pojęcie odrodzenia, które dokonuje się w chrzcie. Jednakże na plan pierwszy wysuwa się tu nauka o nowym stworzeniu.

W pismach Pawłowych spotykamy naprzód tezę, iż człowiek przyjmujący wiarę zostaje wyniesiony do godności dziecka Bożego. Oznacza to wprowadzenie w zupełnie nowy stan bytowania. Sprawczą zasadą tego nowego sposobu bytowania jest Duch Św. Po wtóre, Apostoł często wypowiada również twierdzenie, że to co działo się z Chrystusem, dzieje się także z każdym z Jego uczniów w chrzcie. Jak Chrystus umarł na krzyżu, został pogrzebany i trzeciego dnia zmartwychwstał, tak i przyjmujący chrzest umiera, zostaje pogrzebany i zmartwychwstaje do nowego życia. Apostołowi chodzi tu nie tylko o obraz i porównanie, lecz o doskonałą rzeczywistość. Chce mianowicie pokazać dwa całkowicie odmienne stany bytu i życia, które pozostają w stosunku do siebie jak śmierć i życie, swój zaś początek mają w chrzcie.

Nauka św. Pawła o początku nadprzyrodzonego życia w człowieku wierzącym, zdaniem naszego moralisty, znajduje swój ostateczny wyraz w pojęciu ,nowego stworzenia”. Kto stał się chrześcijaninem, przeżył

94 Nachf. Chr., 87-90.

95 Tam, 90-94; K. Sitt., 33; Meister ruft, 22 n. 
nowe stworzenie. Przemiana sprawiona w człowieku przez chrzest jest stwórczym aktem Boga, tzn. jest zdarzeniem, które z uwagi na przyczynę i skutek jest wyłącznym dziełem Boga. Odmiennie od stwórczego dzieła Bożego na początku wszelkiego bytu przemiana ta jest zdarzeniem nadprzyrodzonego rodzaju, jest owocem krzyżowej śmierci Chrystusa i Jego odkupienia. Stanowi ono nowe stworzenie z tej racji, że sprawia stan całkowicie odmienny od dotychczasowego. Sposób bytowania przyjmającego chrzest staje się tak doskonały, że św. Paweł charakteryzuje go przy pomocy przeciwieństw: życie i śmierć, światło i ciemność, duch i ciało. Godność i wielkość nowego stworzenia uwidacznia się szczególnie w tym, że jest ono przedstawione jako ukształtowanie (,,Umbildung”) człowieka na obraz odwiecznego Syna Bożego.

Porównując Pawłowe pojęcie nowego stworzenia z Janowym pojęciem odrodzenia, dochodzi F. Tillmann do wniosku, że pierwsze z nich uzupełnia drugie ${ }^{96}$. Pod względem treści pojęcia te wprawdzie się pokrywają, niemniej zachodzi między nimi pewna różnica co do sposobu ujmowania spraw. I tak w pojęciu nowego stworzenia mocniej niż w pojęciu odrodzenia zostaje odróżnione to co Boskie od tego co ludzkie, a tym samym dobitniej wykluczone niebezpieczeństwo panteizującego tłumaczenia. Po wtóre, u św. Pawła w większej mierze niż u św. Jana uwydatnia się zadanie moralne, jakie wraz z nowym stworzeniem względnie odrodzeniem przypada wierzącemu. Jest to właściwie tylko różnica stopnia, gdyż zwłaszcza pierwszy List św. Jana często i stanowczo podkreśla niemożność pogodzenia grzechu z człowiekiem odrodzonym. Gdy jednak idzie o sposób ujęcia następstw moralnych odrodzenia lub nowego stworzenia, to św. Jan ujmuje je bardziej statutowo jako żądanie, natomiast u św. Pawła wyrastają one w pełen życia sposób z jego nauki o nowym stworzeniu.

Na zakończenie swych rozważań nad początkiem nowego życia chrześcijanina zwraca F. Tillmann uwagę na tekst $\mathrm{z}$ drugiego Listu św. Piotra (2 P 1, 4), który treściowo dopełnia Janowe pojęcie odrodzenia i Pawłowe pojęcie nowego stworzenia. Wedle tego tekstu istota danych w Chrystusie obietnic Bożych polega na udziale chrześcijanina w samej naturze Bożej, a więc na trwałym uczestnictwie w tym życiu, które właściwe jest Bogu na mocy Jego natury. Zdaniem autora ,,branie udziału w życiu Bożym jest trafnym wyrażeniem na określenie nowego sposobu bytowania, jakim obdarzony został wierzący przez odrodzenie i nowe stworzenie" 97 .

96 Nachf. Chr., 94.

97 Tam, 95. 


\section{c. Dziecięctwo Boże}

Wśród składników teologii moralnej F. Tillmanna nie sposób pominąć dziecięctwo Boże. Ma ono zasadnicze znaczenie dla życia chrześcijańskiego i dla nauki moralnej. Wystarczy tu wspomnieć, że w przekonaniu autora idea dziecięctwa Bożego „obejmuje i uzasadnia (umspannt wie begründet) moralne wymagania chrześcijaństwa w ich pełni" ${ }^{98}$. Poszukując odpowiedzi na pytanie o rolę naśladowania Chrystusa w teologii moralnej F. Tillmanna, trzeba będzie ustalić, w jakim stosunku pozostają do siebie te dwie idee, tzn. idea dziecięctwa Bożego i idea naśladowania Chrystusa. Chcąc określić ten stosunek, musi się wprzód poznać treść zawartą w obu tych ideach. Dziecięctwo Boże ma dla naszego autora jakby dwa wymiary, a mianowicie ontyczny i etyczny. W obecnym kontekście zajmiemy się tylko ontycznym aspektem dziecięctwa Bożego, przekazując jego stronę etyczną późniejszym rozważaniom.

Dziecięctwo Boże - stwierdza nasz moralista — jest „wielkim darem Boga i zadaniem postawionym przez Niego człowiekowi" "99. Dziecięctwo Boże rozpatrywane w aspekcie daru Bożego „trzeba przede wszystkim określić jako właściwy skutek owego pochodzącego z łaski zdarzenia, które jest nazywane odrodzeniem lub zrodzeniem z Boga" ${ }^{100}$. I dalej wyjaśnia autor, że skoro odrodzenie lub zrodzenie $\mathrm{z}$ Boga $\mathrm{w}$ pismach Janowych oznacza prawdziwe odrodzenie i prawdziwe zrodzenie, nie może być wątpliwości, iż ich owocem jest prawdziwe synostwo, stosunek dziecięctwa lub synostwa w prawdziwym słowa znaczeniu. Dziecięctwo Boże nie jest więc dziełem ludzkim. Zwłaszcza w świetle pierwszego Listu św. Jana jest jasne, że tylko ci są dziećmi Bożymi, którzy są zrodzeni z Boga. Autor utrzymuje, że także św. Paweł pisząc, iż ci jedynie są dziećmi Bożymi, których prowadzi Duch Boży (Rz 8,14$)$, ma na myśli rzeczywiste zamieszkanie Ducha Bożego w człowieku wierzącym. To pozwala naszemu moraliście postawić tezę, że ,zamieszkanie Ducha Św. i wspólnota z Chrystusem oznacza dwie zasady, z których wypływa nowe życie chrześcijanina, jego dziecięctwo Boże" ${ }^{101}$.

$\mathrm{Z}$ uwagi na potrzebę określenia wzajemnego stosunku idei dziecięctwa Bożego i idei naśladowania Chrystusa należy szczególnie podkreślić związek naszego dziecięctwa Bożego z Chrystusem. Zdaniem F. Tillmanna w Listach św. Pawła dziecięctwo Boże ukazuje się jako cel wcielenia odwiecznego Syna Bożego ${ }^{102}$. Na innych miejscach autor stwierdza, że uczeń przez Jezusa Chrystusa stał się dzieckiem Bożym, że dziecięctwo Boże

\footnotetext{
98 Tam, 69.

$99 \mathrm{Tam}, 139$.

100 Tam, 106; Meister ruft, 20.

101 Nachf. Chr., 106.

102 Tam, 107.
} 
otrzymaliśmy za pośrednictwem Chrystusa ${ }^{103}$. Pismo św. nie pozostawia żadnej wątpliwości co do tego, że nasze dziecięctwo Boże różni się od Chrystusowego Synostwa Bożego. Chrystus jest jednorodzonym Synem Bożym na mocy swej Boskiej natury, my natomiast. stajemy się dziećmi Bożymi przez podniesienie, przez przyjęcie do godności dziecka Bożego. Jako dzieci Boże, jesteśmy podobni do Boga. W oparciu o liczne wypowiedzi autora można dojść do wniosku, że w idei dziecięctwa Bożego zawarte jest również podobieństwo do Chrystusa. Autor utrzymuje, że godność nowego stworzenia szczególnie w tym się uwidacznia, iż jest ono ukazane przez św. Pawła ,,jako ukształtowanie człowieka na obraz odwiecznego Syna Bożego" "104. $\odot$ tym, co dokonuje się w chrzcie, F. Tillmann za Apostołem pisze, że chrześcijanin ,przyoblekł się w nowego człowieka, który został stworzony na obraz Chrystusa" ${ }^{105}$. Wyniesienie do godności dziecka Bożego - stanowiące owoc chrztu - oznacza zarazem upodobnienie do obrazu Syna Bożego ${ }^{106}$. Jako dziecko Boże, chrześcijanin jest więc upodobniony do Chrystusa. Chodzi tu oczywiście o podobieństwo ontyczne, z którego - jak zobaczymy później - wypływa obowiązek etycznego upodobnienia do Chrystusa. W tym świetle wydaje się być usprawiedliwione zaliczenie dziecięctwa Bożego do ontycznego aspektu idei naśladowania Chrystusa.

B. Nadprzyrodzone siły naśladowania Chrystusa

Zdaniem F. Tillmanna podniesienie człowieka do nowego porządku bytu i życia przez odrodzenie i nowe stworzenie w sakramencie chrztu nie oznacza tylko nowego sposobu bytowania. Z wewnętrzną koniecznością obejmuje ono także napełnienie nowymi, nadprzyrodzonymi siłami uzdalniającymi ochrzczonego do nowego życia, do naśladowania Chrystusa, które odtąd staje się jego zadaniem ${ }^{107}$. To, co dziś nazywamy łaską, oznaczone jest w Nowym Testamencie, zwłaszcza u św. Pawła, dwiema formułami. Jeist to naprzód Duch, który zamieszkuje w człowieku odrodzonym i wywiera wpływ na jego nowe życie jako nadprzyrodzona zasada i siła. To samo wyraża druga formuła „być w Chrystusie” lub „żyć w Chrystusie".

a. Duch 108

Autor utrzymuje, że dopiero św. Paweł utorował w pełni drogę prawdzie o doniosłym znaczeniu Ducha Sw. dla religijno-moralnego życia wszystkich chrześcijan. Odwołując się dó odnośnych tekstów przedstawia

103 Tam, 164, 106.

104 Tam, 93.

105 Verwirklichüng Nachf. Chr. II, 290.

106 Nachf. Chr., 90.

107 Tam, 95; Meister ruft, 24.

108 Nachf. Chr., $96 \mathrm{nn}$. 
on naukę Apostoła w tym względzie. Sama wiara, aczkolwiek jest nieodzownym warunkiem, nie wystarcza do zaistnienia stanu chrześcijanina. To, że stajemy się dziećmi Bożymi i chrześcijanami, jest dziełem Ducha Św. Dla św. Pawła odkupienie i usprawiedliwienie jest dziełem Chrystusa, ale tak samo jest dziełem Ducha. Przedstawiona w ten sposób nauka Apostoła o roli Ducha Sw. pozwala F. Tillmannowi stwierdzić na zakończenie, że Duch Boży jest wewnętrzną siłą życiową, która przenika chrześcijanina i kieruje nim od chrztu aż do zmartwychwstania, przemienia go w nowego, duchowego człowieka ${ }^{109}$. Autor podkreśla również, iż zamieszkanie Ducha Ŝw. zmieniło wprawdzie wewnętrzny stan człowieka 'usprawiedliwionego, jednakże dla osobowości chrześcijańskiej stanowi ono jedynie nadprzyrodzoną podstawę i siłę. Napełnienie Duchem Sw. nie znosi bynajmniej moralnego zadania chrześcijanina, lecz na nowo je stawia i umożliwia dopiero jego spełnienie.

\section{b. Wspólnota bytu $i$ życia z Chrystusem}

Studium Ewangelii św. Jana i Listów św. Pawła pozwala F. Tillmannowi dojść do wniosku, że chrześcijanin pozostaje w jedności życia z Chrystusem, co jest źródłem nadprzyrodzonych sił umożliwiających naśladowanie Go.

Gdy idzie naprzód o Ewangelię św. Jana, autor stwierdza wyraźnie, że ,odkryła ona źródło, z którego nieustannie dopływają do człowieka odrodzonego siły, z pomocą których może on rozwijać i kształtować nałożone mu nowe, osobowo-moralne życie z Boga. Tym wciąż płynącym źródłem siły jest wspólnota życia (Lebensgemeinschaft), a nawet jedność życia (Lebenseinheit) z samym Chrystusem ${ }^{110}$. Prawdzie tej daje św. Jan wyraz w alegorii o szczepie winnym i latoroślach. Podstawą wszelkiego życia chrześcijańskiego i warunkiem jego owocowania jest zjednoczenie z Chrystusem, bycie i trwanie w Nim. Zdaniem autora to, że Ewangelista tak mocno podkreśla niemożność uczynienia czegokolwiek bez życiowego związku z Chrystusem, świadczy, iż chodzi tu o coś więcej niż tylko o jedność sprawioną przez miłość. Te same myśli odnajdujemy w Modlitwie Arcykapłańskiej. Im lepiej uczniowie Chrystusa poznają istotę i działanie Boże oraz żyją odpowiednio do tego poznania, tym bardziej miłuje ich Ojciec tą miłością, jaką umiłował swego Syna; tym bardziej jest w nich obecny Chrystus osobiście (,,in seiner Person”), a nie tylko przez swoją miłość. Podobna treść zawarta jest również w często u św. Jana spotykanej formule ,modlić się, prosić w imię Jezusa”. W języku Pisma św. oznacza to bowiem prosić w Osobie Jezusa, czyli w najściślejszej wspólnocie życia z Nim. 
Ideą wspólnoty życia z Chrystusem, utrzymuje F. Tillmann ${ }^{111}$, o wiele bardziej przeniknięte jest całe nauczanie św. Pawła. Wyrażają ją często w pismach Apostoła powracające formuły „w Panu, w Chrystusie Jezusie”, jak również sformułowania mówiące o przebywaniu Chrystusa w uczniach czy wreszcie zwroty z dopełniaczem (tzw. „Christusgenitive”, np. miłość Chrystusa). Wspólne tym formułom, zdaniem autora, jest to, że zakładają one jedność chrześcijanina z uwielbionym Chrystusem. Liczne teksty pism Pawłowych świadczą, że nie chodzi tu tylko o jedność sprawioną przez miłość. Dla Apostoła jest to osobista obecność Chrystusa w uczniach, której nie można sprowadzać do dziedziny rozważań etycznych czy religijnej symboliki, wszak jest ona wprawdzie mistycznym, ale najbardziej rzeczywistym zdarzeniem. Ta obecność Chrystusa w człowieku wierzącym zaczyna się wraz z chrztem. Takie ujmowanie spraw przez św. Pawła stało się możliwe dopiero po uwielbieniu Chrystusa, a więc z chwilą kiedy zaczął On bytować w nowy, duchowy sposób.

Ukazując naukę św. Pawła o życiu w Chrystusie autor zwraca uwagę na znaczenie tej prawdy dla chrześcijańskiego życia moralnego: nowe istnienie zobowiązuje i uzdalnia człowieka wierzącego do nowego życia. Zdaniem naszego moralisty ,bycie w Chrystusie z całą słusznością wolno określić jako podstawę wszelkiego życia chrześcijańskiego, jako istotę każdego chrześcijańskiego zobowiązania moralnego i jako istotnie chrześcijańską normę moralną", ${ }^{112}$.

Zestawienie nauki św. Jana o wspólnocie życia z Chrystusem z nauką św. Pawła o byciu w Chrystusie pozwala autorowi dojść do wniosku, że nie różnią się one co do swej treści. Obaj Apostołowie stwierdzają, że chrześcijanin pozostaje w nieprzerwanej, najbardziej wewnętrznej wspólnocie życia z Chrystusem. Bez tej wspólnoty nie ma prawdziwie chrześcijańskiego życia, którego owocność również całkowicie od niej zależy. Przy czym u św. Pawła bardziej jest widoczne, że chodzi o uwielbionego Chrystusa i że ta jedność jest najwyższą rzeczywistością, że jest obiektywnym stosunkiem bytowym (,Seinsverhältnis'), przebywaniem (,Innesein") osoby ludzkiej w Osobie Chrystusa i odwrotnie ${ }^{\mathbf{1 1 3}}$.

$\mathrm{Na}$ zakończenie rozważań nad nadprzyrodzoną ontologią naśladowania Chrystusa trzeba za F. Tillmannem dodać, że ukazany tu sakramentalny stosunek do Chrystusa musi się stać również stosunkiem moralnym ${ }^{\mathbf{1 1 4}}$. Stwierdzenie to pozwala nam przejść do etycznego aspektu idei naśladowania Chrystusa.

111 Tam, 102-104.

112 Tam, 104.

113 Tam, 105.

114 Tam, 55. 


\section{Aspekt etyczny naśladowania Chrystusa}

Pochodząca z daru Bożego nowa, nadprzyrodzona rzeczywistość sprawiona przez chrzest $\mathrm{w}$ człowieku stanowi dla chrześcijanina moralne zadanie i cel. „Ale to pochodzące $z$ laski odrodzenie i nowe stworzenie pisze F. Tillmann - oznacza dla nich (tj. chrześcijan) zobowiązanie, zadanie i powołanie. W trafny sposób wyraża to krótka formuła pozdrowienia, którą-Paweł pozdrawia Koryntian jako uświęconych w Chrystusie i jako powołanych do świętości, to znaczy jako ludzi, którzy na mocy otrzymanej w chrzcie istotnej (wesenhaft) świętoścj powołani są do religijno-moralnego uświęcenia swego życia" ${ }^{115}$. Przy porównaniu pojęcia odrodzenia z pojęciem nowego stworzenia zostało wspomniane, że w przekonaniu autora „Paweł mocniej niż Jan zaznacza zadanie moralne, jakie wraz z nowym stworzeniem względnie odrodzeniem przypada wierzącemu" ${ }^{116}$. To samo trzeba powiedzieć o często u św. Pawła powracającej formule „w Chrystusie Jezusie". Formuły te - stwierdza F. Tillmann - wyrażają tę prawdę, że „Chrystus stał się zasadą ich (tj. chrześcijan) nowego życia, że weszli oni w najściślejszą wspólnotę bytu i życia z Chrystusem, która nie tylko uwarunkowana jest łaską, lecz zawiera w sobie także pełnię religijno-moralnych wymagań. $\mathrm{Z}$ tego bytowego i życiowego stosunku będącego wprawdzie mistyczną, ale pełną życia rzeczywistością - wyrasta dla każdego chrześcijanina nieuniknione wymaganie, by swoje religijno-moralne życie kształtował i przeżywał zgodnie z tą wspólnotą z Chrystusem" "117. Również i dziecięctwo Boże oprócz aspektu ontycznego ma aspekt etyczny, jest ,wielkim darem Boga i zadaniem postawionym przez Niego człowiekowi” ${ }^{118}$. O dzieciętwie Bożym pisze autor, że „nie oznacza ono tylko nowej, pochodzącej z łaski rzeczywistości, w którą włączony został wierzący; oznacza ono także cel do osobistego osiągnięcia i religijno-moralne zadanie. Chrześcijanin stał się dzieckiem Bożym, by w swoim codziennym życiu coraz bardziej nim się stawać" ${ }^{119}$. W świetle tych wielu, choć tylko przykładowo zacytowanych wypowiedzi, nie ulega wątpliwości, iż na tę nadprzyrodzoną rzeczywistość, jaką sprawia w człowieku chrzest, patrzy F. Tillmann zarówno z ontycznego, jak i etycznego punktu widzenia. Dla chrześcijanina jest ona nie tylko pochodzącym z łaski darem Bożym, ale i religijno-moralnym zadaniem i celem.

$\mathrm{Z}$ kolei nasuwa się następne pytanie, a mianowicie jaka jest treść tego zadania, które niesie z sobą nowa, nadprzyrodzona rzeczywistość. Od strony treści zadanie to różnie bywa określane przez F. Tillmanna. I tak za-

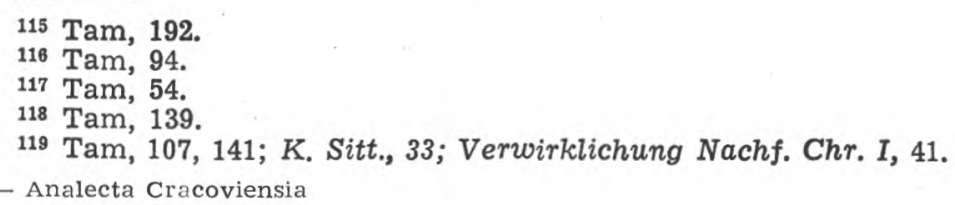

28 - Analecta Cracoviensia 
daniem chrześcijanina jest stać się dzieckiem Bożym, religijno-moralną osobowością; jest doskonałość moralna, religijno-moralne uświęcenie. Inaczej mówiąc, dziecięctwo Boże, osobowość moralna, doskonałość chrześcijańska w naśladowaniu Chrystusa ukazuje się jako ideał. Ten, kto naśladuje Chrystusa, staje się dzieckiem Bożym, osobowością chrześcijańską, zdobywa doskonałość moralną. Jednym słowem, dziecięctwo Boże, osobowość, doskonałość stanowią treściowe spełnienie, urzeczywistnienie naśladowania ${ }^{120}$.

A. Zadanie moralne chrześcijanina

a. Osobowość moralna

„Chrystus, pisze F. Tilmann, stworzył ideał osobowości chrześcijańskiej, który odtąd staje się zadaniem i celem każdego chrześcijańskiego dążenia moralnego" ${ }^{121}$. W szczególności jest ono zadaniem naśladowania Chrystusa, gdyż „stać się religijno-moralną osobowością winno byó zadaniem tych, których On zaprosił, by Go naśladowali i przystali do Jego uczniów" ${ }^{122}$. Na innym miejscu czytamy, że „naśladowanie Chrystusa spotyka ideę osobowości moralnej" ${ }^{123}$. Z zacytowanych tu zdań widać, że moralista nasz rozróżnia osobowość chrześcijańską i osobowość moralną. Przez to terminologiczne rozróżnienie chce on zaakcentować nadprzyrodzony charakter chrześcijańskiego zadania moralnego. Można powiedzieć, że osobowość chrześcijańska jest osobowością moralną w wymiarze przyrodzonym i nadprzyrodzonym.

Zanim szczegółowo przedstawimy za autorem treść idei osobowości moralnej naprzód kilka uwag natury ogólnej. Interesujące nas tu pojęcie wypracowane zostało stosunkowo niedawno ${ }^{124}$. Zawarta $\mathrm{w}$ nim treść ma dwojaki charakter, jest mianowicie treścią związaną z bytowaniem i działaniem. W tillmannowskiej idei osobowości moralnej dostrzegamy naprzód metafizyczne pojęcie osoby, przy czym autor opowiada się za boecjuszowską definicją osoby jako jednostki natury rozumnej. Bycie osobą (,Personsein") stanowi ontyczną podwalinę osobowości moralnej. Na tym bytowym fundamencie wyrasta z kolei cel, którego urzeczywistnienie jest zadaniem człowieka. Można więc powiedzieć, że osobowość moralna jest to po prostu osoba rozpatrywana w aspekcie dynamicznym, w aspekcie

120 Nachf. Chr., 57.

121 K. Sitt., 29.

122 Nachf. Chr., 67.

123 Tam, 48.

124 Hadrossek P. za K. Wernerem utrzymuje, że scholastyka dobrze wypracowała metafizyczne pojęcie osoby, nie zdołała jednak dotrzeć do etycznego pojęcia osobowości. Zrodziło się ono dopiero pod wpływem reakcji na formalizm Em. Kanta. Dzięki M. Schelerowi, mianowicie, systematycy poznali i wykorzystali pojęcia osoby moralnej i osobowości. Por. Hadrossek P., Die Bedeutung des Systemgedankens für die Moraltheologie in Deutschland seit der Thomas-Renaissance, K. Zink Verlag München 1950, 319. 
stawania się; jest to "osoba zadana samej sobie do urzeczywistnienia" ${ }^{125}$. Tę samą myśl wyraża F. Tillmann jeszcze inaczej. Zastanawiając się nad istotą osobowości, trzeba uświadomić sobie przede wszystkim różnicę zachodzącą pomiędzy bytem poszczególnego człowieka i tzw. wartościowym charakterem („Wertcharakter”) jego osoby. Charakter ten można również nazwać idealnym etosem danej jednostki. W języku teologicznym mówi się tu o myśli Bożej, o Bożej idei człowieka, czyli jakim go widział Bóg w chwili stworzenia. Ta myśl Boża jest miarą i zadaniem każdego z osobna ${ }^{126}$.

Pojęcie osobowości moralnej znane jest różnym systemom filozoficznym i etycznym. I dlatego nasuwa się pytanie, jakie szczgółowe treści widzi F. Tillmann w tym pojęciu. Moralista nasz odcina się stanowczo przede wszystkim od pojęcia osobowości właściwego filozofii idealistycznej. Jego zdaniem idea osobowości moralnej $\mathrm{w}$ prawdziwym znaczeniu zawiera w sobie następujące treści szczegółowe ${ }^{127}$.

- Rozwój wszystkich dyspozycji i uzdolnień. W przekonaniu autora człowiek nie jest nigdy kimś gotowym, ukończonym, lecz ciągle kimś stającym się. Wszczepiona w człowieka w chwili stworzenia myśl Boża, Boża koncepcja człowieka jest podobna do zarodka naglącego do rozwoju. Pierwszym koniecznym wymaganiem stąd wypływającym jest rozwój wszystkich dyspozycji, uzdolnień i sił, jakimi Bóg obdarzył każdego z osobna, jakich - gdy idzie o rodzaj i miarę - tylko jemu udzielił. O dojrzałej, doskonałej osobowości może być mowa jedynie tam, gdzie nastąpił pełny rozwój wszystkich dyspozycji, gdzie spożytkowane zostały wszystkie uzdolnienia i siły. Mając na uwadze sam rozwój, a nie sprawę pierwszeństwa i znaczenia, w całościowym obrazie osobowości nie można, zdaniem F. Tillmanna, robić różnicy pomiędzy uzdolnieniami ducha i ciała. Wszystkie one bez wyjątku domagają się rozwoju, są zadaniem i obowiązkiem nałożonym człowiekowi. Prowadzącą na manowce jednostronnością byłaby chęć pojmowania osobowości jako pełnego rozwoju jedynie duchowej strony człowieka. Osobowość jest wprawdzie w pierwszym rzędzie doskonałością ducha, ale to nie znaczy, że sprowadza się ona w całości do tej ostatniej, że wyłącznie doskonałość ducha stanowi osobowość.

- Równomierność i harmonia. W idealnym obrazie osobowości, utrzymuje nasz moralista, rozwój dyspozycji i uzdolnień musi być równomierny, harmonijny. W imię tej równomierności trzeba więc z jednej strony troszczyć się o wszechstronność, a z drugiej strzec się wszelkiej jedno-

125 Nachf. Chr., 58.

126 Tam, 58.

${ }_{127}$ Tam, 59-65; K. Sitt., 29. 
stronności. Podobnie jak nie wolno dopuścić do tego, by jakaś dyspozycja marnowała się, by jakieś uzdolnienie leżało odłogiem, tak też nie można akcentować i rozwijać jednej dyspozycji czy jednego uzdolnienia kosztem innych. W uchybieniu przeciw równomierności tkwi, zdaniem autora, przyczyna tego, że wszelka jednostronność i przesada w życiu wielkich ludzi nas razi. Można ich podziwiać, a nawet rozumieć na tle osobistych uwarunkowań i historycznej konieczności, jednakże nie stanowią oni doskonałych osobowości. Nasz moralista zastrzega się, że przedstawionego tu celu nie należy pojmować $\mathrm{w}$ duchu etycznego optymizmu. Trzeba pamiętać, że chodzi tu właśnie o cel, do którego ciągle się zmierza, a którego być może nigdy nie zdoła się osiągnąć. W szczególności chrześcijanin, którego celem i zadaniem jest doskonałość Boża, winien być świadom, że cel ten może w pelni osiągnąć w życiu przyszłym dzięki udoskonaleniu płynącemu z oglądania Boga.

- Duchowość. Przez duchowość w kontekście ideału osobowości rozumie autor moc ducha i jego wolność. Mocny duchowo jest człowiek wówczas, gdy wywalcza sobie wewnętrzną wolność i jest w jej trwałym posiadaniu. To wymaga uniezależnienia się od działających w człowieku niższych sił zmysłowych, które stawiają opór tej wolności i grożą jej unicestwieniem. Do tego uniezależnienia się od niższych sił świata wewnętrznego musi dojść niezależność od świata zewnętrznego - zarówno rzeczy, jak i osób. Duchowość w rozumieniu F. Tillmanna oznacza, po wtóre, wolność ducha pojętą jako samostanowienie i kształtowanie samego siebie od wewnątrz. Prawdziwa osobowość jest w pełnym tego słowa znaczeniu autonomiczna: sama nadaje sobie prawa swego moralnego bytu, stawania się i życia, wedle tego jak je odnajduje w poznaniu własnego życia. Tego rodzaju samostanowienie nie ma jednak nic wspólnego z subiektywizmem lub wręcz z rozpasaniem moralnym. W każdym momencie i w każdym szczególe decyzji moralnej jest ono podporządkowane temu prawu, które znajduje w sumieniu i rozumie.

- Odrębność, indywidualność. Ludzie różnią się od siebie nie tylko wyglądem zewnętrznym, lecz także swymi wewnętrznymi dyspozycjami i uzdolnieniami. To co odrębne i niepowtarzalne w człowieku jest wolą Boga Stwórcy. Poznać to, uznać i dać temu wyraz w działaniu jest nie tylko prawem, lecz także moralnym obowiązkiem. Do nieodzownych treści pojęcia osobowości trzeba, zdaniem F. Tillmanna, zaliczyć również indywidualność. Stawanie się i dojrzewanie osobowości jest nierozdzielnie związane $\mathrm{z}$ rozwojem cech jednostkowych każdego człowieka. Indywidualność stanowi dla poszczególnego człowieka zarówno jego granicę, jak i bogactwo. Od indywidualności zależy, jak i w jakim znaczeniu każdy z osobna może i musi być osobowością: każdy może i musi stać się osobowością w ramach swej odrębności. Gdy idzie o wzajemny stosunek indywidual- 
ności i osobowości, należy strzec się dwóch skrajności, a mianowicie niedoceniania jak i przeceniania indywidualności. Tak więc indywidualność nie utożsamia się z osobowością, ale jest jej nieodzownym składnikiem. Ona to sprawia, że powszechny ideał osobowości odmiennie kształtuje się u każdego z osobna; jest ona szczególną formą ucieleśnienia osobowości. - Społeczny wymiar osobowości moralnej ${ }^{128}$. Ukazując przyjętą przez F. Tillmanna ideę osobowości moralnej, trzeba jeszcze zwrócić uwagę na to, co można by nazwać społecznym wymiarem tej osobowości. Ideał osobowości moralnej wyklucza tu czysto indywidualistyczną interpretację. Autor mocno podkreśla to, że człowiek nie jest tylko jednostką, od samych swych początków bowiem jest jak najściślej związany ze społecznością. Do arystotelesowsko-tomistycznego uzasadnienia twierdzenia, że człowiek z natury swej jest. istotą społeczną, dodaje nasz moralista następujące: dopiero przez spotkanie naszego ,,ja” z ,,ja” drugiego człowieka stajemy się osobowością i poznajemy swoją osobową moc stanowienia, zarówno swoje granice, jak i odpowiedzialność. Dopiero w zetknięciu z „ja” drugiego uświadamiamy sobie swoją jednostkową odrębność i różnicę, przeżywamy siebie samych w swej osobowej istocie. Tu uświadamiamy sobie, że stoimy przed decyzją, którą podejmując stajemy się ostatecznie osobą dopiero przez to, że poznajemy i przeżywamy z jednej strony swoje odniesienie do ,ja” drugiego człowieka, z drugiej zaś swoją moc samostanowienia i odrębność, jak również zobowiązanie swojego ,ja”. względem ,,ja" drugiego.

Wewnętrzny i konieczny związek jednostki ze społecznością ma wedle F. Tillmanna dwojakie znaczenie dla osobowości moralnej. Oznacza naprzód ubogacenie tej osobowości: dopiero w społeczności rozwija ona całość swych uzdolnień, poprzez społeczność również otrzymuje ona najbardziej wartościowe dobra prawdy i kultury. Po wtóre, związek jednostki ze społecznością wyznacza osobowości pewne granice, gdyż żąda od niej włączenia się do zadań i celów danej społeczności oraz podporządkowania się władzy. Celem uniknięcia nieporozumień autor określa bliżej charakter tego ograniczenia. Wyższą wartość posiada osobowość, dlatego żądanie włączenia się do zadań i celów społeczności oraz żądanie podporządkowania się władzy może być tylko względne. Społeczność ma prawo domagać się od osobowości moralnej najwyższej ofiary, ale nigdy tego, by zrézygnowała ona $\mathrm{z}$ samej siebie.

Wszystko to pozwala F. Tillmannowi podać następujące określenie osobowości moralnej: „Osobowością moralną nazywamy więc tego, kto swoje cielesno-duchowe siły w wewnętrznej wolności i samostanowieniu oraz w stałej świadomości swego zobowiązania wobec społeczności i w ży-

128 Tam, 65 n; K. Sitt., 80. 
ciowym udziale w jej duchowym i kulturalnym dziedzictwie doprowadza do pełnego i równomiernego rozwoju odpowiadającego jego odrębności" ${ }^{129}$.

Jak wspomnieliśmy na początku rozważań o osobowości moralnej, nasz moralista utrzymuje, iż zadaniem i celem naśladowania Chrystusa jest stać się osobowością moralną. Lektura Nowego Testamentu prowadzi do stwierdzenia, że w nauczaniu Chrystusa ani raz nie pojawia się słowo osobowość. Wobec tego nasuwa się pytanie, jakim słowem oznaczona jest w Piśmie św. treść pojęcia osobowości moralnej. To pozwala nam przejść do następnego zagadnienia, jakim jest dziecięctwo Boże.

\section{b. Dziecięctwo Boże}

Zdaniem F. Tillmanna ,pojęcie osobowości Ewangelii, jak i Nowego Testamentu w ogóle, znajduje swój ostateczny wyraz w podstawowym i wiążącym dla każdego chrześcijanina żądaniu, by stać się dzieckiem Bożym" ${ }^{130}$. Na innym miejscu tę samą myśl wyraża autor następująco: „W żądaniu skierowanym do każdego ze swych uczniów, by stać się prawdziwym dzieckiem Bożym, wysunął On (tj. Chrystus) ideał osobowości, który co do wielkości i głębi nie może być przewyższony" ${ }^{131}$. Chcąc się przekonać, czy w idei dziecięctwa Bożego zawiera się faktycznie idea osobowości moralnej, trzeba zapoznać się z treścią tej pierwszej.

W idei dziecięctwa Bożego rozpatrywanego w aspekcie etycznym widzi autor następujące treści: ${ }^{132}$

- Mieści się tu naprzód najwyższy wymiar moralnego wymagania i działania. Mówi o tym Chrystus w Kazaniu na Górze, nakazując miłować nieprzyjaciół i dążyć do doskonałości Ojca niebieskiego. Postępowanie Boga ukazane tu jest nie tylko jako wzór i miara postępowania ucznia; wzorowanie się na tym postępowaniu jest drogą do stania się dzieckiem lub synem Bożym. Zdaniem autora twierdzenie, że dopiero naśladowanie przykładu Boga Ojca czyni nas prawdziwymi dziećmi Bożymi, jest ważne zarówno, gdy idzie o ten szczególny przypadek miłości nieprzyjaciół, jak i o całość życia chrześcijańskiego. Ukazana tu zależność pełne uzasadnienie znajduje w użytym przez Chrystusa obrazie ojcostwa i synostwa. Jak fizyczne pochodzenie i pokrewieństwo wyraża się w podobieństwie rysów i w całej postawie, tak i duchowe pokrewieństwo, zrodzenie z Boga musi stworzyć podobieństwo do Ojca niebieskiego, które zgodnie ze swoją naturą winno się uwidocznić w przymiotach moralnych człowieka odrodzonego. Tym samym zadanie moralne chrześcijanina jest tu ukazane w najwyższym wymiarze i głębi. Mając na uwadze osobowość,

129 Nachf. Chr., 67.

130 Tam, 68.

131 K. Sitt., 30.

132 Nachf. Chr., 68-73; K. Sitt., 30; Meister ruft, 9-13. 
nasz moralista stwierdza, że w idei dziecięctwa Bożego mieści się cel i wymaganie rozwoju moralnych dyspozycji i uzdolnień, który to rozwój ośmiela się przybliżyć do niedościgłego wzoru wszelkiego prawdziwego życia, do samego Boga.

- Gotowość do każdej ofiary ze względu na to zadanie. „Wielkości tego zadania, pisze F. Tillmann, odpowiada niezmierna powaga, z jaka Jezus przedstawia je swoim uczniom. Domaga się go ono w całości i niepodzielnie bierze na swoją służbę" ${ }^{133}$. Chrystus nigdy nie osłabia swoich wymagań, co najlepiej widać na przykładzie młodzieńca chcącego wprawdzie pójść za Nim, ale stawiającego pewne warunki.

- Doskonałe oddanie się woli Ojca. Zdaniem autora negatywnie oznacza to zerwanie ze wszystkim co przeciwne Bogu i grzeszne; pozytywnie - całkowite związanie z Bogiem. Oddanie się Bogu dokonujące się w miłości jest właściwie dopiero osobowościowotwórcze. Wiążąc człowieka całkowicie z wolą Bożą stwarza ono tę, opartą na związaniu z prawdą i dobrem, wolność, która jest cechą dziecka Bożego, a zarazem warunkiem prawdziwej osobowości. Bez wewnętrznej wolności, bez panowania nad tym, co człowieka chce ściągnąć w dół, bez wzniesienia się ponad to co przemijające, nie można w ogóle stać się osobowością. W nauczaniu Jezusa uwolnienie od ciężaru grzechu i od tego co przemijające dokonuje się właśnie przez doskonałe oddanie się woli Ojca niebieskiego. Dla Jezusa i dla każdego Jego ucznia wola Boża staje się jednym wielkim prawem, które obejmuje całe myślenie i chcenie, dążenie i życie chrześcijanina.

- Na koniec w idei dziecięctwa Bożego zawiera się wedle naszego moralisty „niezależność od bogactwa i posiadania, przewaga nad światem i jego siłą" ${ }^{134}$. Jest to nieodzowne uzupełnienie stworzonej przez oddanie się woli Bożej wolności, której przydana tu zostaje wolność w stosunku do rzeczy i ludzi.

Podsumowując swoje rozważania nad treścią idei dziecięctwa Bożego F. Tillmann pisze: „Tak więc Jezus chce uczynić ludzi dziećmi Bożymi, które z całym swym bytem i życiem spoczywają w Bogu i w łączności z Nim znajdują siłę do pełnego rozwoju wartości własnej osobowości, do niewyczerpalnej dzielności, do doskonałej wolności i samodzielności. Ideał osobowości, który całkowicie przeniknięty jest wiarą i głęboką pobożnością, któremu jednak z drugiej strony nic prawdziwie ludzkiego nie jest obce; ideał, w którym osobowość moralna i święty stają się jednym" ${ }^{135}$. Gdy idzie o znamienne rysy ukazanego przez Chrystusa ideału osobowości moralnej, autor akcentuje szczególnie to, że ideał ten jest

133 Nachf. Chr., 69.

$134 \mathrm{Tam}, 72$.

135 Tam, 72; Meister ruft, 18. 
związany z Bogiem. Jako taki różni się on istotnie od pojęcia osobowości właściwego etyce idealistycznej. Ożywiona duchem Chrystusa, stwierdza na zakończenie, nauka katolicka musi odrzucić zarówno czysto indywidualistyczną interpretację ideału osobowości, jak i-wszelki wygórowany kolektywizm ${ }^{136}$.

\section{c. Doskonałość moralna}

Pochodzące $\mathrm{z}$ łaski odrodzenie i nowe stworzenie, jak o tym była mowa wyżej, oznacza dla chrześcijanina zadanie dążenia do doskonałości moralnej. „W trafny sposób wyraża to, pisze F. Tillmann, krótka formuła pozdrowienia, którą Paweł pozdrawia Koryntian jako uświęconych w Chrystusie i jako powołanych do świętości, to znaczy jako ludzi, którzy் na mocy otrzymanej w chrzcie istotnej świętości powołani są do religijno-moralnego uświęcenia swego życia". W tym samym miejscu nieco dalej czytamy:, Ale ta doskonała świętość i święta doskonałość w religijno-moralnym znaczeniu nie jest jeszcze faktem, jak są nim chrzest i odrodzenie, lecz jest celem, do którego ze wszystkich swoich sił i wsparty łaską Bożą musi dążyć człowiek odrodzony, i jest zadaniem, które musi on spełnić” ${ }^{137}$. Zdaniem autora „wszystkie miejsca Nowego Testamentu pokazują, że chrześcijańska doskonałość nie jest zadaniem nielicznych, szczególnie oḅdarzonych łaską, lecz powszechnym celem, właściwym zadaniem każdego ochrzczonego bez wyjątku" ${ }^{138}$. Ten sam cel przyświeca również i naśladowaniu Chrystusa. O ascezie powiada F. Tillmann, że jest nieodzowną drogą naśladowania Chrystusa i że każdy musi ją podjąć, jeśli ,,chce być uczniem Pana i osiągnąć postawiony mu tu cel doskonáłości" ${ }^{139}$. Na temat słów z ewangelii św. Mateușza 5, 48 pisze autor, że Chrystus ukazał w nich cel, ,na który nastawione jest wszelkie naśladowanie Chrystusa: doskonałość chrześcijańską lub religijno-moralne udoskonalenie" ${ }^{140}$.

W świetle licznie tu zacytowanych wypowiedzi widać, że zadaniem, jakie niesie z sobą nowa nadprzyrodzona rzeczywistość, jest dążyć do doskonałości, co stanowi także zadanie i cel naśladowania Chrystusa. Wobec tego nasuwa się pytanie o stosunek tego zadania do ukazanych wyżej zadań: osobowości moralnej i dziecięctwa Bożego. Jeśli się weźmie pod uwagę treść doskonałości moralnej, trzeba powiedzieć, że jest ona zawarta zarówno w idei osobowości moralnej, jak i dziecięctwa Bożego. Przez doskonałość chrześcijańską rozumie autor najwyższe dostępne człowiekowi tu na ziemi religijne i moralne udoskonalenie. Jest ona doskonałym

\footnotetext{
136 Nachf. Chr., 82.

137 Tam, 192; Meister ruft, 55.

138 Nachf. Chr., 197; Meister ruft, 54.

139 Nachf. Chr., 235, 214, 190.

140 Meister ruft, 53.
} 
spełnieniem woli Bożej w swym własnym życiu, urzeczywistnieniem Bożej idei człowieka ${ }^{141}$.

Zbierając $\mathrm{w}$ jedno dotychczasowe rozważania o zadaniu moralnym chrześcijanina, otrzymujemy następujący, obraz tego zadania: w naśladowaniu Chrystusa zostaje ukazany chrześcijaninowi ideał, czyli zadanie i cel, który w języku etyki nosi miano osobowości moralnej, a w języku Pisma św. - dziecięctwa Bożego. Przy czym stać się osobowością moralną lub dzieckiem Bożym znaczy także posiąść doskonałość chrześcijańską dostępną człowiekowi wspartemu łaską.

$\mathrm{Tu}$ nasuwa się następne pytanie, a mianowicie pytanie o to, w jaki sposób uczeń Chrystusa ma urzeczywistniać ukazany mu ideał. Zdaniem autora drogą do tego celu jest naśladowanie wzoru. To stwierdzenie pozwala nam przejść do następnego zagadnienia.

B. Naśladowanie wzoru - drogą do osiągnięcia celu

Prawdzie tej daje F. Tillmann wyraz na wielu miejscach swego podstawowego dzieła. I tak komentując Chrystusowy nakaz miłości nieprzyjaciół z Kazania na Górze (Mt 5, 44) pisze: „Istotna treść tego słowa leży w tym, że z postępowania Boga czyni ono nie tylko wzór i miarę postępowania uczniów, lecz że także w stosowaniu się do niego (in seiner Befolgung) widzi drogę, na której dopiero stają się oni dziećmi lub synami Bożymi". Zasady tej nie można, zdaniem autora, zacieśniać do przykazania miłości nieprzyjaciół, ,ponieważ w tym pojedynczym przypadku jak i w stosunku do całości życia chrześcijańskiego jest ważne, że dopiero naśladowanie przykładu Boga Ojca czyni z człowieka Jego prawdziwe dziecko, prawdziwego syna Bożego" ${ }^{142}$. Zaparcie się siebie samego, branie na siebie Chrystusowego krzyża nie może sprowadzać się do jednorazowego aktu, lecz musi stanowić „onus diei”, a więc brzemię, które każdego dnia musi się brać na ramiona, ,jak długo na drodze naśladowania zdąża się do celu" ${ }^{143}$. W szczególności naśladowanie Chrystusa jest drogą do ukształtowania osobowości chrześcijańskiej, do stania się dzieckiem Bożym. Powiada bowiem nasz moralista, że ,w powstawaniu religijno-moralnej osobowości na drodze naśladowania Chrystusa trzeba rozróżnić dwa stopnie" ${ }^{144}$. Chrystus jest wzorem pobożności, od Niego uczą się jej ci wszyscy, „którzy w Jego naśladowaniu stali się dziećmi swego Ojca $\mathrm{w}$ niebie" ${ }^{145}$. Jak widać z zacytowanych tekstów, przez naśladowanie Boga i Chrystusa chrześcijanin ma dojść do wyznaczonego sobie celu, ma urze-

\footnotetext{
141 Nachf. Chr., 193 mn; K. Sitt., 34; Meister ruft, 56.

142 Nachf. Chr., 68, 191, 51.

143 Tam, 228.

144 Tam, 84.

145 Verwirklichung Nachf. Chr., I, 46.
} 
czywistnić ukazany mu ideał dziecięctwa Bożego, względnie osobowości chrześcijańskiej.

Naśladowanie oznacza tu zatem pewne działanie, moralne postępowanie człowieka. Przy czym autor z naciskiem podkreśla, że chodzi mu o prawdziwe naśladowanie, a nie kopiowanie. W idei naśladowania Chrystusa zawarte jest to szczególne działanie i postępowanie moralne człowieka, które określamy mianem naśladowania. Tak staje przed nami kolejne zadanie polegające na ustaleniu, co F. Tillmann rozumie przez naśladowanie jako działanie. Naprzód przedstawimy jego pogląd na naśladowanie w ogólności, następnie zaś powiemy o tym szczególnym rodzaju naśladowania, jakim jest naśladowanie Chrystusa.

\section{a. O naśladowaniu w ogólności}

Zacznijmy od analizy jednej z tillmannowskich definicji naśladowania. Definicja ta brzmi następująco: „Naśladowanie zatem oznacza ujęcie (Erfassen) wartościowej treści wzoru opierające się na pełnym-miłości oddaniu się, i znowu z miłosnego oddania się zrodzone odtwarzanie (Nachformen) przeżytego wzoru we własnym bycie i życiu według miary, jaka każdemu jest wyznaczona przez granice jego istoty, jego stanowiska jak i jego zadania" ${ }^{146}$. W świetle tej definicji w naśladowaniu można wyróżnić dwa elementy: ujęcie wartościowej treści wzoru i odtwarzanie przeżytego wzoru we własnym bycie i życiu.

Ujęcie wartościowej treści wzoru.

Na pytanie, co znaczy naśladować kogoś, daje F. Tillmann następującą odpowiedź: „Znaczy to obrać go sobie za wzór, za przykładem którego chce się przekształcić i formować własne życie" ${ }^{147}$. Podobnie pisze na innym miejscu: „Kto posiada wzór, stara się o to, by ten wzór naśladować, tzn. stać się do niego podobnym lub takim samym" ${ }^{148}$. Moralista nasz wyraża tu tę oczywistą prawdę, że wzór i naśladowanie są ze sobą ściśle związane; że dopiero wówczas może być mowa o naśladowaniu, kiedy posiada się już wzór. Stąd pierwsze pytanie: co względnie kto może być wzorem? Dodajmy od razu, że chodzi tu o wzór moralny, o naśladowanie w sensie etycznym. Często bowiem mówi się o naśladowaniu czegoś; jeśli natomiast mamy na uwadze naśladowanie w sensie etycznym, to jest ono zawsze naśladowaniem kogoś. Inaczej mówiąc, wzorem moralnym jest zawsze i wyłącznie osoba i to osoba wartościowa. Wyraźnie stwierdza to sam autor, gdy pisze, że ,przedmiotem tego naśladowania jest mianowicie tylko wartościowa osoba (die werterfüllte Person)" ${ }^{149}$. Mocno trzeba

\footnotetext{
146 Nachf. Chr., 49; Meister ruft, 8.

147 Meister ruft, 7.

148 Nachf. Chr., 49.

149 Um k. Sitt., 15; Nachf. Chr., 50.
} 
podkreślić, że wzorem jest nie jakakolwiek osoba, lecz jedynie osoba wartościowa. Gdyby więc osoba nie wykazywała tej wartościowości, nie mogłaby stanowić przedmiotu naśladowania. W naśladowaniu etycznym chodzi o wartość osobowościowej treści wzoru („Wert des Persongehaltes”), czyli o tę wartość, którą reprezentuje wzór jako osoba. Ta właśnie wartościowość osoby decyduje o tym, że tę a nie inną osobę obieramy za wzór. „Kto posiada wzór - pisze F. Tillmann - stara się o to, by ten wzór naśladować (...), ponieważ wartość osobowościowej treści swego wzoru przeżywa on wewnętrznie jako moralne żądanie, które się do niego zwraca" ${ }^{150}$. Wprost i bezpośrednio autor wyjaśnia tu, dlaczego zachodzi naśladowanie już obranego wzoru. Zachodzi ono mianowicie dlatego, że wraz z wzorem staje przed jego posiadaczem moralne żądanie, wymaganie. Naśladujący w taki właśnie sposób przeżywa wartość osobowościowej treści wzoru, przeżywa ją wewnętrznie jako moralne żądanie. Jednym słowem, w naśladowaniu etycznym chodzi zawsze o wartość treści osobowościowej wzoru lub po prostu o treści osobowościowe „Personalitätsgehalte"). One to, jeśli tak można powiedzieć, przykuwają naszą uwagę, dostrzegamy, zauważamy je w osobie, która dzięki nim staje się naszym wzorem. Tę samą prawdę nasz moralista wyraża w prostszy sposób bez posługiwania się językiem etyki wartości. Powiada mianowicie, że naśladowanie zakłada ,osobę-wzór, której pojmowanie życia (Lebensauffassung) i prowadzenie życia ukazało się nam jako wielkie dobro, właśnie jako wzorcze" 151.

Skoro już wiemy, że wzorem jest zawsze jakaś wartościowa osoba, trzeba z kolei wyjaśnić, w jaki sposób dostrzegamy tę wartość, tę osobowościową treść wzoru. Nie wchodząc w szczegóły, można powiedzieć, że tym dostrzeganiem rządzą ogólne prawa ujmowania (,Erfassen”) wartości. Trzeba naprzód zauważyć, iż w rozważaniach naszego autora na temat naśladowania raz po raz pojawiają się różne formy czasownika ,er leben” - przeżywać, doznawać, doświadczać. Tak np. naśladujący ,przezywa wewnętrznie wartość osobowościowej treści wzoru jako moralne żądanie”. Jest tu też mowa o ,przeżywanym stosunku (das "erlebte Verhältnis)" osoby do osobowościowej treści wzoru, o odtwarzaniu ,przeżytego wzoru" 152. Wszystko to wskazuje, że w naśladowaniu w obu jego etapach doniosłą rolę odgrywa całe emocjonalne życie człowieka. Szczególna zaś rola przypada tu miłości. „Droga do tego poznania (w którym życie osoby-wzoru ukazuje się jako wielkie dobro — wyj. moje) prowadzi przez miłość do owego wzoru. Dopiero w jej świetle osoba-wzór ukazuje się w swej niepowtarzalnej wartości i w jej porywającym żarze

\footnotetext{
150 Nachf. Chr., 49.

151 Meister ruft., 7.

152 Nachf. Chr., 49 n.
} 
wzrasta decyzja, by stać się takim, jaką stała się ona. Naśladować kogoś znaczy więc obrać go sobie za wzór, ponieważ jest się przejętym miłością ku niemu" ${ }^{153}$. Na innym miejscu mówi autor, że dopiero pełen miłości szacunek otwiera przystęp do osoby wzorczej, że pierwowzór ujmuje się w głębokiej miłości, że ujęcie wartościowej treści wzoru spoczywa na pełnym miłości oddaniu się. Podobnie z pełnego miłości oddania się rodzi się również odtwarzanie wzoru; naśladowanie kogoś w kształtowaniu własnego bytu moralnego opiera się na miłości do osobowościowej treści wzoru ${ }^{154}$. Miłość zatem jest niezbędna zarówno do ujęcia wartości osobowościowej treści wzoru, jak i do podjęcia decyzji naśladowania, upodobnienia się do wzoru, odtworzenia go w sobie. Można powiedzieć, że jest to „poznanie” i decyzja w miłości i z miłości. Innymi słowy, nie może być mowy o naśladowaniu w obu jego etapach bez miłości.

Odtwarzanie wzor u w osobistym bycie i życiu.

Naśladowanie nie sprowadza się oczywiście do samego wyboru wzoru, do samego ujęcia wartościowej treści wzoru. Wzór obiera się przecież po to, by za jego przykładem ,przekształcać i formować własne życie”, by „stać się podobnym lub takim samym" ${ }^{155}$. Przy czym autor wyraźnie zastrzega się, że naśladując wzór „stajemy się takimi, jakim jest wzór jako osoba, a nie tym; czym on jest”. Inaczej mówiąc, uczeń „nie może ani dokładnie stać się tym, czym jest jego mistrz, ani nie może on zrezygnować ze swego, które on i tylko on posiada" ${ }^{156}$. Tak staje przed nami problem granic naśladowania. Właściwe rozumienie naśladowania wymaga przede wszystkim bacznego zwrócenia uwagi na to, że zarówno osoba wzorcza, jak i osoba naśladująca posiada swój jednostkowy, niepowtarzalny byt, swoją indywidualność. Gdy idzie o osobę-wzór, to autor wyraźnie stwierdza, że zachowuje ona swój jednostkowy byt. Innymi słowy, „bycie wzorem" w niczym nie narusza jednostkowego bytu osoby-wzoru. Każdy wzór, utrzymuje F. Tillmann, posiada dwie konkretne właściwości, które wyznaczają granice naśladowania. Chodzi mianowicie o to, że istnieją tego rodzaju normy osobowe, które odnoszą się tylko do danej jednostki. Mấ to swoją podstawę bądź w jej niepowtarzalnym bycie, bądź też w szczególnym wymaganiu Boga względem niej. Dochodzi tu jeszcze określona, niepowtarzalna sytuacja historyczna, w której te właściwości są urzeczywistnione ${ }^{157}$. Inaczej mówiąc, „to co wzorcze ukazuje się w obrazie mistrza w pełnej rzeczywistości życia, które tylko jemu zostało darowane przez Boga w odrębności jego zadania jak i treści, i które na zawsze jest i pozostaje czymś szczególnym, jemu tylko zada-

153 Meister ruft, 7.

154 Nachf. Chr., 49 n; Meister ruft, 8; Um k. Sitt., 15.

155 Meister ruft, 7; Nachf. Chr., 49.

156 Nachf. Chr., 50; Meister ruft, 7.

157 Nachf. Chr., 49. 
nym" ${ }^{158}$. Przedmiotem naśladowania, jak już wiadomo, jest zawsze jedynie wartościowa osoba. Jednakże nie wszystko w tej osobie jest do naśladowania: „Indywidualność, pisze F. Tillmann, pozostaje nie tylko nieosiągalna, lecz także w ogóle nie powinna być naśladowana" ${ }^{159}$.

Swój jednostkowy, niepowtarzalny byt, swoją indywidualność posiada również osoba naśladująca. Uczeń w stosunku do mistrza „stanowi własną odrębność i jednorazową rzeczywistość w szczególnej sytuacji historycznej”. I dlatego „,nie może on ani dokładnie stać się tym, czym jest mistrz, ani nie może zrezygnować ze swego, które on i tylko on posiada" ${ }^{160}$. Można więc powiedzieć, że skutek naśladowania wzoru, czyli odtworzenie wzoru („Nachbild”) nie jest jego kopią czy fotografią. Wzór pokazuje uczniowi sposób, w jaki jego mistrz przeżył swoje życie i wypełnił swoje zadanie życiowe. Naśladowanie żąda od ucznia takiej formy urzeczywistnienia, która jest dla niego odpowiednia i uwarunkowana jego sytuacją życiową. Innymi słowy, samo naśladowanie jest pozostawione własnej indywidualności. Owoc naśladowania („Nachbild”) zawsze wykazuje pewne elementy pochodzące $\mathrm{z}$ własnej inicjatywy, „wypływa tak samo z kształtowania (pochodzącego) z własnej spontaniczności jak i ze spojrzenia na wzór". Tylko w ten sposób, zdaniem autora, można się ustrzec fałszywego tradycjonalizmu, który wartość należącą do przeszłości i uwarunkowaną historycznie przenosi nad wartości teraźniejszości i przyszłości. A taki tradycjonalizm z konieczności musiałby zaistnieć wówczas, gdyby przez naśladowanie dany typ osobowy w całości miał być przenoszony w rzeczywistość. Dlatego też prawdziwe naśladowanie jest i musi być zawsze stwarzaniem na nowo (,eine Neuschöpfung”) swego wzoru $^{161}$. Jako takie różni się ono od naśladownictwa. Unicestwieniem prawdziwego naśladowania byłoby zatem spełnianie 'aktów wzoru w ten sam sposób, w jaki je wzór spełniał („Gleichvollzug der Akte”), czy też kopiowanie jego postępowania i zachowania. Prawdziwe naśladowanie dalekie jest także od posłuszeństwa rozumianego jako czynienie tego, czego chce lub co czyni ktoś drugi ${ }^{162}$.

\section{b. Naśladowanie Chrystusa}

Z kolei nasuwa się pytanie, czy i w jakiej mierze powyższe uwagi na temat naśladowania w ogólności odnoszą się również do naśladowania Chrystusa. Stanowisko autora nie jest w tym względzie jednolite. I tak w „Der Meister ruft” stwierdza on, iż wszystko, co zostało powiedziane o naśladowaniu w ogólności, „odnosi się również do naśladowania Chry-

158 Meister ruft, $7 \mathrm{n}$.

159 Nachf. Chr., 50.

160 Tam, 49; Meister ruft, 7.

161 Nachf. Chr.; 50; Um k. Sitt., 15.

162 Nachf. Chr., 49 n; Meister ruft, 8. 
stusa" ${ }^{163}$. Natomiast w swym podstawowym dziele po uwagach na temat naśladowania w ogólności pisze, że ,istotnie inaczej przedstawiają się sprawy w katolickiej nauce moralnej opierającej się na objawieniu Bożym w Chrystusie i włączonej w wiarę w nie (tj. objawienie)" ${ }^{164}$. Źródło tej istotnej różnicy leży w pierwszym rzędzie w przyjętym przez tę naukę wzorze mającym stanowić przedmiot naśladowania jej wyznawcy.

- Katolicka nauka moralna w przekonaniu F. Tillmanna jest nauką opartą na wierze, która swoje najdoskonalsze i najwłaściwsze źródło ma w objawieniu Bożym. Lektura źródeł objawionych, zwłaszcza Nowego Testamentu, pozwala autorowi stwierdzić, że „w nauce Pana ukazuje się jako wzór zarówno Bóg, Ojciec niebieski, jak i On sam, Jego jednorodzony Syn posłany ludziom" ${ }^{165}$. W teologii moralnej naśladowania Chrystusa pod pewnym względem pierwsze miejsce zajmuje ten wzór, jakim jest Chrystus. W pewnej mierze jest to zgodne ze stawianiem spraw przez samego Chrystusa. „O wiele częściej i dobitniej, pisze F. Tillmann, sam Jezus objawia się swym uczniom jako pierwowzór i wzór w powołującym słowie jak i wzorczym czynie" ${ }^{166}$. Nie chodzi tu oczywiście o dwa istotnie różne wzory, skoro na prośbę Filipa o pokazanie Ojca, Pan Jezus odpowiedział: „Kto mnie zobaczył, zobaczył także i Ojca” (J 14, 9). Jak zaraz o tym będzie mowa, wzór, jakim jest Chrystus, posiada tego rodzaju przymioty, które psychologicznie czynią go bliskim człowiekowi. Określiwszy w ten sposób wzajemny stosunek tych wzorów, spróbujmy podać bliższą charakterystykę wzoru obowiązującego w teologii moralnej naśladowania Chrystusa.

Zdaniem autora w katolickiej nauce moralnej „wzór przedstawia typ osobowy, który tylko nịewłaściwie można tak nazwać, ponieważ jest on jednorazowy i nieosiągalny" ${ }^{167}$. I dalej wyjaśnia, gdzie leży zasadnicze źródło tej jednorazowości i nieosiągalności wzoru. Jednorazowy i nieosiągalny jest on „nie tylko ze względu na zadanie, jakie Ojciec złożył w Jego ręce, lecz także dlatego, że dla wierzącego jest On Synem samego Boga" ${ }^{168}$. Jednorazowość i niẹosiągalność nie stanowią jednak jedynych cech przyjętego przez teologię moralną wzoru. Nie można bowiem zapominać o tym, że wzorem jest wprawdzie Syn Boży, ale jest to Syn Boży wcielony. „W osobie Jezusa Chrystusa jako wcielonego Syna Bożego, stwierdza nasz moralista, wierzący uczeń ujmuje pełnię Bóstwa poprzez przezroczystość człowieka z ciała i krwi, który we wszystkim stał się nam podobny $\mathrm{z}$ wyjątkiem grzechu" ${ }^{169}$. Fakt ten ma zasadnicze znaczenie dla

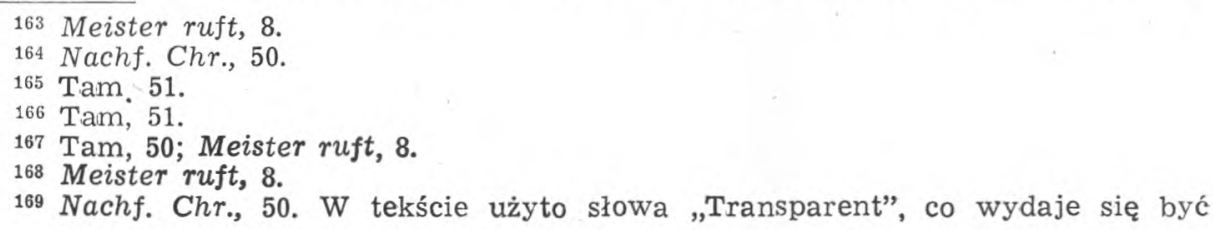


naśladowania Chrystusa. Ponieważ chodzi tu o Syna Bożego, dla człowieka wierzącego wzór osobowy jest tutaj wzorem o absolutnej i doskonałej wartościowości. Jako taki może domagać śię pełnego miłości uznania (,Wertschätzung”) o najwyższej sile i najgłębszej intymności, a zarazem je umożliwiać. Inaczej mówiąc, wraz z tą absolutną wartościowością wzoru dany jest obowiązęk naśladowania wiążący w sumieniu. Po wtóre, Chrystusowy wzór jak najbardziej odpowiada naturalnemu dążeniu tkwiącemu w każdym człowieku, by mianowicie w dostępny sobie sposób wznieść się ponad siebie samego ku świętości. A właśnie w tym wzorze ukazuje się doskonałość Boża urzeczywistniona w sposób bliski człowiekowi (,,in einer menschenförmingen und menschennahen Verwirklichung”). W tym świetle Chrystusowe żądanie by stać się doskonałym jak Ojciec niebieski, nie oznacza bynajmniej zniechęcającej i paraliżującej niemożliwości ani też nie może być uważane za grzeszną zarozumiałość. Przeciwnie, jest ono i działa jako przyjęte w miłości i wsparte łaską wezwanie do najwyższego rozwoju, do jakiego człowiek może być powołany i uzdolniońy ${ }^{170}$.

Po uwagach na temat wzoru obowiązującego w teologii moralnej naśladowania Chrystusa przejdźmy z kolei do odtwarzania tego wzoru w swym własnym życiu i bycie. Tu trzeba mieć na uwadze przede wszystkim podstawowe rozróżnienie pomiędzy prawdziwym naśladowaniem i czysto zewnętrznym naśladownictwem. Bezpośrednio po ukazaniu różnicy zachodzącej pomiędzy prawdziwym naśladowaniem i czysto zewnętrznym naśladownictwem autor stwierdza, że ,jedynie to (tzn. prawdziwe naśladowanie - echte Nachfolge) jest tym, co również my rozumiemy przez naśladowanie Chrystusa" ${ }^{171}$. Stwierdzenie, że naśladowanie Chrystusa nie jest zewnętrznym naśladownictwem, odróżnia wprawdzie naśladowanie od tych wszelkich działań, które mimo pewnego podobieństwa do naśladowania nie są prawdziwym naśladowaniem. To odróżnienie, chociaż ma zasadnicze znaczenie dla właściwego rozumienia naśladowania, niewiele jednak mówi o samym naśladowaniu, o jego wewnętrznej treści. Na pytanie, czym jest to szczególne działanie nazwane naśladowaniem Chrystusa, muszą więc odpowiedzieć inne, bliższe jego określenia i definicje, o ile oczywiście można je odnaleźć w dziele F. Tillmanna.

Podsumowując naukę Ewangelii o Bogu Ojcu i Chrystusie jako wzorze, moralista nasz pisze: „Naśladować Jezusa znaczy stawać się i być takim, jakim był On w służbie Bogu i człowiekowi, i to nie tylko w jednorazowej decyzji, lecz codziennie, stale" ${ }^{172}$. Nie zostało tu jednak wyjaś-

pomylką; winno chyba być „Transparenz”. Tekst równoległy z „Der Meister ruft” (s. 8) ma ,in der Gestalt".

170 Nachf. Chr., 51; Meister ruft, 8.

171 Um k. Sitt., 15.

172 Nachf. Chr., 53. 
nione, co i jak musi czynić człowiek, by stawać się i być takim, jakim był Chrystus. Wyjaśnia to autor na innym miejscu pisząc, że „kto przyznaje się do Niego (tj. do Chrystusa) i do Jego naśladowania, musi więc również być usposobiony, jak On był usposobiony, i postępować, jak On postępował; czynić to, czego On się domagał" ${ }^{173}$. W zacytowanym tu zdaniu na szczególne podkreślenie zasługuje naprzód to, że naśladujący Chrystusa ma w swym postępowaniu upodobnić się do swego Mistrza. O tym, że chodzi tu o upodobnienie, świadczy użyte przez autora słowo „wie jak", a nie „was - co". Z rozważań o naśladowaniu w ogólności wiadomo, że stajemy się takimi, jakim („wie”) jest wzór jako osoba, a nie tym, czym (,was") on jest. Po wtóre, w rozpatrywanym określeniu naśladowania trzeba także mocno zaakcentować jego ostatnią część, a mianowicie słowa: „czynić to, czego On się domagał”. Wyjaśniając definicję naśladowania w ogólności autor - jak o tym była mowa - stwierdził, że chodzi tu o takie działanie moralne, które dalekie jest zarówno od samego tylko naśladownictwa, jak i posłuszeństwa pojętego jako czynienie tego, czego chce ktoś drugi. Tymczasem ten, kto chce naśladować Chrystusa, winien czynić to, czego domagał się Chrystus. Mamy tu zatem do czynienia z doniosłą różnicą pomiędzy naśladowaniem w ogólności a naśladowaniem Chrystusa. Ze zrozumiałych'względów zagadnieniu temu trzeba poświęcić nieco więcej uwagi.

W nauczaniu Chrystusa, utrzymuje F. Tillmann, spotykamy się z takimi wymaganiami, które odnoszą się do każdego ucznia i są nieodzowne. Nie wypływają one $\mathrm{z}$ danej sytuacji, ani też nie określają zadań niektórych tylko ludzi. Przeciwnie, są one ,zawsze i dla wszystkich ważne, ponieważ są podstawowymi wymaganiami religijno-moralnego życia, jak ono musi być kształtowane w naśladowaniu Chrystusa". Na plan pierwszy wysuwa się żądanie zmiany usposobienia lub wymaganie całkowitego nawrócenia. A to $\mathrm{z}$ tej racji, że ,,jedynie wtedy powstaje miejsce dla kształtowania życia, które odpowiada Jego wzorowi jak i Jego przepowiadaniu, gdy to (tj. zmiana) się dokonało" 174. Jak wynika z powyższego, autorowi chodzi tu o to religijno-moralne życie, które ma się kształtować w naśladowaniu Chrystusa, a które zarazem ma być zgodne z wzorem i nauczaniem Chrystusa. Można więc powiedzieć, że dla naśladowania Chrystusa „miarodajne” są zarówno Jego wzór, jak i Jego przepowiadanie. Podobnie o katolickiej nauce moralnej F. Tillmann pisze, że jej „zadaniem jest przedstawić naukowo naśladowanie Chrystusa. Na podstawie pism Nowego Testamentu określa ona wyłaniający się z osobowości Jezusa Chrystusa i z Jego wymagań obowiązek, by żyć jak chrześcijanin" ${ }^{175}$.

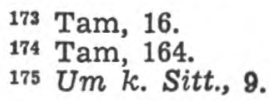


W szczególności zadaniem tej nauki jest pytać „,o istotę i treść religijności, jak wyłaniają się one dla naśladowania Chrystusa z nauki i przykładu Pana" ${ }^{176}$. W świetle zacytowanych -zdań również należy stwierdzić, że naśladowanie Chrystusa nie ogranicza się do tej religijno-moralnej treści, którą uczeń odnajduje w Jego osobowości czy wzorze. Obejmuje ono także religijno-moralną treść zawartą $\mathrm{w}$ Jego wymaganiach lub w Jego nauczaniu.

W ten sposób dokonaliśmy rekonstrukcji poglądów F. Tillmanna na naturę teologii moralnej i na ideę naśladowania Chrystusa. Rekonstrukcja ta stanowi nieodzowne przygotowanie do podjęcia naszego zasadniczego pytania o rolę idei naśladowania Chrystusa w tillmannowskiej teologii moralnej. Zanim jednak przejdziemy do następnego etapu naszych poszukiwań ustosunkujemy się po krótce do odtworzonych tu poglądów bońskiego moralisty.

Wysunięte przez F. Tillmanna postulaty pod adresem katolickiej teologii moralnej w większości są słuszne i nadal aktualne. Zastrzeżenia muszą jednak wzbudzić zarówno tillmannowska koncepcja teologii moralnej jako „Glaubenswissenschaft”, jak i wnioski wyprowadzone z niej przez autora. Nie ulega wątpliwości, że teologia moralna jest nauką opartą na wierze, a nie na samym tylko rozumie. Z tej właśnie racji jej zasadniczymi źródłami są żódła wiary, a więc Pismo św. i Tradycja Kościoła. Słuszny sam w sobie postulat oparcia teologii moralnej na Piśmie św., ścisłego związania jej z nim czy też ubiblijnienia, jest nie do przyjęcia w wydaniu tillmannowskim. Niektóre wypowiedzi autora prowadzą do wniosku, iż w jego przekonaniu teologia moralna winna ograniczyć się do religijno-moralnych treści biblijnych. Tak np. stwierdza on wyraźnie, iż katolicka nauka moralna „,nie może być niczym innym jak naukowym wypracowaniem i przedstawieniem chrześcijańskiego życia moralnego, jego zadań i obowiązków, jak są one zawarte w nadprzyrodzonym objawieniu, dokładniej - w nauczaniu Pana" ${ }^{177}$. W tym przekonaniu utwierdza nadto postulat wyłączenia z teologii moralnej obcego jej materiału i przydzielenia go odpowiednio etyce filozoficznej, psychologii czy nauce prawa. Zatem mielibyśmy tutaj do czynienia z tym, co dziś nazywają „,biblicyzmem” ${ }^{178}$. Stanowisko F. Tillmanna w tym względzie nie jest jednak jednolite. Już przy charakterystyce Pisma św. jako źródła teologii moralnej podkreśla on jego niewystarczalność, wszak nie daje ono ani gotowego, ani systematycznego, ani - co najistotniejsze - pełnego wykładu norm chrześcijańskiego życia moralnego. Nic więc dziwnego, że wśród

176 Verwirklichung Nachf. Chr. I, 12.

177 Um k. Sitt., 10.

178 Por. np. H. Juros, Pozytywizm biblijny $w$ teologii moralnej, SThV 12 (1974) f. $2,45-75$. 
źródeł teologii moralnej umieszcza autor poznanie rozumowe. I słusznie. Ale jak to pogodzić z twierdzeniem, iż teologia moralna winna się ograniczyć do treści biblijnych?

Wydaje się, iż na Tillmannową obronę „czystości” teologii moralnej doniosły wpływ wywarła obawa przed etyką niezależną. Niekiedy odnosi się wrażenie, że autor utożsamia etykę czysto filozoficzną z etyką niezależną. Tymczasem historia etyki zna systemy etyczne czysto rozumowe a zarazem teistyczne, uznające Boga za ostateczny fundament i rację wyjaśniającą obiektywnego i absolutnego porządku moralnego. Uzasadnione jest zdecydowane odcięcie się autora od etyki niezależnej. Teologia moralna skorzysta jednak z usług swoiście pojętej etyki, choć - jak zaznaczono - stanowisko autora nie jest jednolite w tym względzie. Dla F. Tillmanna jest to etyka ,z wiary”, gdyż człowieka widzi ona ,zawsze już w świetle wiary i zwraca się do naturalnego człowieka, który istnieje tylko w całości przyrodzonego i nadprzyrodzonego bytu ludzkiego", a jej zadaniem jest „,w całym człowieku ...odkryć jedną stronę, naturalną, która jest i pozostaje włączona w całość" ${ }^{179}$. Taka koncepcja etyki jest raczej odosobniona. Jeśli w odróżnieniu od teologii moralnej opartej na Objawieniu, jest etyka nauką czysto rozumową, to jak może ona patrzeć na człowieka ,zawsze już w świetle wiary”.

Do dziś trwa ożywiona dyskusja nad stosunkiem etyki filozoficznej i teologii moralnej ${ }^{180}$. Wydaje się, iż w tej sprawie nie powiedziano jeszcze ostatniego słowa. Czy jednak jest do przyjęcia tillmannowska propozycja $\mathrm{w}$ tym względzie? Nie jest łatwo odpowiedzieć na to pytanie, gdyż dodatkową trudność stanowi tu — jak widzieliśmy — brak jednolitego stanowiska autora. Na pewno nie do przyjęcia byłoby radykalne odcięcie teologii moralnej od etyki filozoficznej, co prowadziłoby do pozytwizmu biblijnego. Z drugiej strony, jak słusznie podkreśla F. Tillmann, teologia moralna nie może być zwykłą mieszaniną treści biblijnych ¡ etýcznych. Nie sposób przeczyć, iż konieczne jest rozróżnienie tych treści. Jak widzieliśmy, nasz moralista proponuje utworzenie z treści etycznych przedsionka do teologii moralnej. Ta jednak propozycja nie tyle jest rozróżnianiem, ile raczej rozdzielaniem.

Jakkolwiek miałyby się sprawy $\mathrm{w}$ płaszczyźnie teoretycznej, trzeba stwierdzić, iż w praktyce treść swojej teologii moralnej czerpie F. Tillmann niemal wyłącznie z nauczania Chrystusa i św. Pawła - mimo deklaracji, iż źródłem teologii moralnej jest Objawienie Boże w swej całcści. Przejmuje również liczne treści etyczne i to zarówno w tzw. mo-

179 Nachf. Chr., 26.

180 Por. np. Wojtyła K., Etyka a teologia moralna, w: „Znak”, 1967, 1077-1982; Styczeń T., Etyka czy teologia moralna. Tam, 1083-1095; Inlender'B., Dwie koncepcje stosunku etyki filozoficznej do teologii moralnej, w: SThV, 1968, f. 1, 71-86. 
ralnej ogólnej (jak choćby znaną nam już ideę osobowości moralnej), jak zwłaszcza w moralnej szczegółowej. W praktyce więc boński moralista odchodzi od swych teoretycznych założeń.

Jeśli chodzi z kolei o tillmanowską ideę naśladowania Chrystusa, to zaznaczono już, iż odbiega ona od idei naśladowania przyjmowanej na ogół w etyce wzoru. Współcześni zarzucali nawet naszemu moraliście, że rozszerzył pojęcie naśladowania. Dzisiaj nie stawiano by mu raczej takiego zarzutú, gdyż utrzymuje się przekonanie, że biblijna idea naśladowania obejmuje te treści, jakie odnajdujemy $\mathrm{w}$ tillmanowskiej idei naśladowania Chrystusa ${ }^{181}$.

\section{IMITATION DU CHRIST DANS LA THÉOLOGIE MORALE DE F. TILLMANN}

$R$ és u m é

Les théologiens moralites depuis plusieurs décennies s'efforcent de renouveler leur discipline. Ils sont convaincus de la particulière importance du propre principe morral pour ce but. La solution de ce problème exige beaucoup de travaux monographiques où on analyse et critique les singuliers nouveaux projets de la théologie morale. Cet article, dont le thème est le rôle de l'idée de suivre le Christ dans la théologie morale de F. Tillmann, se place dans ce courant. Sa première partie (présentée ici) apporte la reconstruction de la pensée de cet auteur concernant la théologie morale en tant que la science théologique ainsi que la reconstruction de l'idée de suivre le Christe acceptée par lui.

Sa thèse la plus fondamentale paraît être celle de la théologie morale comme la science de foi (Glaubenswissenschaft). C'est pouquoi elle se distingue essentiellement de l'éthique philosophique, et surtout de l'éthique immanente", qui est seulement la science de raison (Vernunftwissenschaft). La Révélation divine constitue la meilleure et la plus propre source de la théologie morale. Elle est fondamentalement et de tous cotés liée avec Révélation divine: dans sa méthode ainsi que dans son contenu. La source de la théologie morale est aussi la vive personne du Jésus Christ de même que la raison humaine. La méthỏde de la théologie morale doit être principalement positive et spéculative. Selon F. Tillmann la place de la casuistique est dans la théologie pastorale. Etant une science basée sur la foi la théologie morale exige ses propres fondements. L'ancienne morale générale ne constitue pas ces fondements car elle est un mélange de la théologie morale, de l'éthique, de la psychologie et de la jurisprudence. Ainsi faut-il exclure de la théologie morale tout ce qui appartient à l'éthique ou aux sciences semblables. Une spécifique éthique ne peut être qu'un „vestibule” de la théologie morale. La théologie morale est une science normative. Pourtant elle n'a pas besoin de chercher et de prouver la vérité morale comme obligatoire car elle la trouve d'avance dans des

181 Hörmann K., Nachfolge Christi. Lexikon der Christlichen Moral, Tyrolia Verlag Innsbruck Wien München 1969, $849 \mathrm{nn}$; Hofmann R., Moraltheologische Erkenntnis- und Methodenlehre. M. Hueber Verlag München 1963, $235 \mathrm{n}$. 
sources de la foi comme une vérité divine et obligatoire dans la conscience. La théologie morale doit être en l'étroite connexion avec la dogmatique. Il faut aussi qu'elle solit une science destinée à chaque chrétien et non seulement aux confesseurs. Cela exige une langue comprehensible et surtout sa présentation positive. Elle doit être en premier lieu une science de la vertu et il faut englober questions ascético-mystiques dans son contenu.

La deuxième partie nous donne une reconstruction de l'idée de suivre le Christ. F. Tillmann y voit deux couches: l'une ontologique et l'autre éthique. On donne le premier nom aux certains faits surnaturels de la vie chrétienne qui constituent une source de la possibilité et de l'obligation de suivre le Christ. Une naissance de Dieu ou une renaissance, une création de nouveau et une filiation divine constituent le fondement surnaturel de l'imitation du Christ. L'Ésprit et une communion en être et vivre avec le Christ sont des forces de cette imitation. Cette réalité surnaturelle apporte un devoir moral: elle fait le chrétien non seulement capable mais aussi l'oblige à devenir une personnalité morale, un enfant de Dieu. Le chrétien reconnaît et réalise son devoir moral en suivant le Christ (une couche éthique de l'idée d'imitation). Dans l'imitation éthique F. Tillmann distingue deux étapes: la première consiste à percevoir le contenu de valeur de l'exemple, la deuxième - à former cet exemple dans son propre être et vivre. Cette formation est une création de nouveau et non une reproduction. Les principes généraux de l'imitation de l'exemple personnel valent aussi (en principe) pour l'imitation de cet exemple particulier du Jésus Christ. Pourtant l'idée d'imitation acceptée par F. Tillmann (même sous son aspect éthique) ne s'identifie pas avec celle de l'éthique d'exemple. Il est ainsi puisque l'idée d'imitation du Christ contient des valeurs que le disciple trouve dans son exemple ainsi que le contenu moral des exigences et de l'enseignement du Christ.

En terminant on a fait une brève critique de la pensée de $\mathrm{F}$. Tillmann. Cette critique rencontre un obstacle principal car ses opinions ne sont pas concordantes entre elles-même. La plupart de ses postulats est juste. Sa conception de la théologie morale comme Glaubenswissenschaft est la plus discutable. En se basant sur certaines énonciations de F. Tillmann il faudrait constater que la théologie morale devrait se limiter au contenu moral biblique. On ne peut pas accepter ce qu'il dit de la rélation de l'éthique philosophique (singulièrement conçue) avec la théologie morale. Certes, la théologie morale ne peut pas être un mélange de la théologie morale, de l'éthique ou de la psychologie. Sans doute il faut distinguer la théologie morale et l'éthique philosophique, mais on ne peut pas les séparer radicalement comme le veut $\mathrm{F}$. Tillmann. Il faut aussi tenir pour une chose singulière son projet de l'éthique ,de foi" pensée comme un „vestibule” de la théologie morale. En outre on aperçoit que F. Tillmann ne met pas en pratique surtout ses postulats concernant la „pureté” de la théologie morale.

S'il s'agit de l'idée de suivre le Christ les contemporains à F. Tillmann lui reprochaient qu'il élargissait cette idée. Aujourd'hui on ne pourrait plus lui faire ce reproche car on en est d'accord que l'idée biblique d'imitation contient le contenu que nous retrouvons dans l'idée de suivre le Christ proposée par F. Tillmann. 